\title{
Rapid Induction of Ageing Character in Brandy Products - Part I. Effects of Extraction Media and Preparation Conditions
}

\author{
F.P. van Jaarsveld ${ }^{1 *}$, S. Hattingh ${ }^{2}$, P. Minnaar ${ }^{1}$ and M. Blom ${ }^{3}$ \\ (1) ARC Infruitec-Nietvoorbij**, Private Bag X5026, 7599 Stellenbosch, South Africa \\ (2) Department of Medical Physiology, University of Stellenbosch, P.O. Box 19063, Tygerberg, 7505, South Africa \\ (3) Distell Group Limited, P.O. Box 184, 7599 Stellenbosch \\ Submitted for publication: July 2008 \\ Accepted for publication: October 2008 \\ Key words: Unmatured pot-still brandy, oak wood, ageing character, brandy quality, flavour compounds
}

\begin{abstract}
The purpose of this study was to investigate the use of different wood types and treatments, and extraction media to induce rapid ageing of brandy. Extracts were prepared from American and French oak, specially prepared and supplied by a cooper, and from commercially obtained oak; both representative of different toasting levels, including untoasted, light, medium and heavy toasted. To extract the wood components, wood chips in either 55\% (v/v) neutral wine spirits or water media were boiled under reflux. Distillation was followed by either open (higher boiling temperature) or closed (vacuum or reduced pressure - lower boiling temperature) concentration of the decanted solvent by 45,65 and $85 \%(v / v)$. The concentrated extracts were fortified. Screened extracts were added to unmatured pot-still brandy and aged for eight months at room temperature in glass containers. Controls were stored below $0^{\circ} \mathrm{C}$. Matured and unmatured (control) pot-still brandy samples were analyzed for wood-derived congeners by means of HPLC and GC. This article focuses on the effects of the extraction media, and on level and method of concentration (open and reduced pressure) on sensory quality and chemical composition. The treatments that gave acceptable extracts, and the best overall quality pot-still brandy were those that entailed (1) using ethanol instead of water as extraction medium, and (2) levels of concentration above $45 \%(\mathrm{v} / \mathrm{v})$. Open and reduced-pressure concentrations showed little difference in the quality of the products yielded. Treatments yielding the most acceptable extracts and best overall quality pot-still brandy generally also contained higher concentrations of volatile and less volatile wood-derived congeners. Multivariate data analysis was conducted on the pot-still brandy samples representing the different treatments. Discriminate analysis provided better separation of samples than principal component analysis.
\end{abstract}

Freshly distilled brandies generally have "sharp" sensory characteristics and are traditionally matured in oak barrels for several years to impart complex aromas and flavours and produce a premium product. Maturation reactions are complex and involve extraction of wood components, evaporation of lowboiling point compounds from the distillate, reactions between the components of the distillate, and interactions of wood and distillate components. Dissolution of wood components is thought to be of prime importance (Litchev, 1989; Conner et al., 1994). Wood is acknowledged to add value to the quality of spirits during ageing (Marticardi \& Waterhouse, 1999). Oak wood has been used for well over two thousand years to promote the ageing of alcoholic beverages. The qualities of oak wood which favour its use for the aging of spirits include its mechanical and working properties (durability, hardness, pliability, permeability, and the presence of wide multiseriate rays and tylose), and the extractable compounds that it contains (mainly tannins and aromatic components). Oak wood also has the ability to inhibit rotting organisms which might otherwise produce changes in the composition of the spirits (Litchev, 1989; László, 1995; Singleton, 1995; Chatonnet,
1999; Pérez-Coello et al., 1999). Among the many factors known to influence final quality, the most important contributor is undoubtedly the oak barrel in which maturation takes place. During the time that the raw distillate spends in the barrel, major changes occur in the chemical composition of the spirit, resulting in a product which has mellowed and become more acceptable to the palate (Baldwin et al., 1967; Wagener, 1986). The uses of barrel alternatives are closely allied to the barrel-making tradition from which they evolved (Firstenfeld, 2002).

Despite the positive impact on brandy quality, ageing in wooden barrels does have a downside. Costs increase in proportion to the length of the ageing period because capital is tied up. Wooden barrels are expensive, and are difficult to clean and maintain. Evaporation from wooden barrels is higher than from stainless steel tanks. Also, if the wood quality and workmanship are poor, the quality of the spirits will be negatively affected and evaporation losses will increase. Furthermore, new barrels lose their extractable substances after a few years of use, and must be replaced. Treatment with oak chips, especially charred or toasted chips, is considered to hasten brandy ageing (Singleton \& Draper, 1961). The simplest

*Corresponding author: e-mail: VjaarsveldF@arc.agric.za

**The Fruit, Vine and Wine Institute of the Agricultural Research Council

Acknowledgements: The authors wish to thank the Agricultural Research Council and the South African Wine Industry (Winetech) for financial support. Special thanks to Marieta van der Rijst for statistical analysis of the data, and to Neil Jolly for assistance in the compilation of brandy evaluation scorecards. 
method of adding wood-derived compounds is the use of oak chips, which are increasingly used for the maturation of many brandies (Mosedale \& Puech, 1998). Subject to some limitations, using oak chips is good cellar practice, legally permitted and a common commercial practice (Singleton \& Draper, 1961). Oak chips of various sizes, which have undergone different heat treatments, are now commercially available and are used to compensate for the low levels of extractables remaining in old barrels. Such barrels may nevertheless be used to provide a "barrel-environment". Alternatively, renewable stacks of planks placed in large steel maturation tanks may be used for the production of brandies. Among the few additives that are authorised for the production of appellation d'origine contrôlée (AOC) eaux-de-vie are wood extracts (boisés). Oak extracts obtained by the traditional method of preparation, by extracting oak chips with boiling water, are usually devoid of most volatile components, consisting primarily of oak tannins or their degradation products (Mosedale \& Puech, 1998). More sophisticated extracts are available, derived from an infusion or extraction of oak wood that may have previously been subjected to either physical or chemical treatments to promote the degradation of macromolecules. In general, even these extracts, either in liquid form or as a powder after lyophilisation, primarily contain phenolic compounds and polysaccharide, with low concentrations of lignin-derived compounds (Mosedale \& Puech, 1998). The addition of such substances to brandies results in imbalances of phenolic compounds, ligno-complex, aromatic acids and aldehydes in the hydro-alcoholic medium. With different methods of extraction there is no reason why extracts containing higher concentrations of those compounds identified as influencing flavour, such as aromatic aldehydes and whiskey lactone, should not be available. These extracts would allow increased control and manipulation of the final taste.

There are five ways in which wood components may influence the flavour of the final brandy product. These are: (1) toasting of the oak barrel; (2) extraction of monomer compounds present in a free state in lignin; (3) formation of compounds by reaction of alcohol with lignin; (4) further conversion of extracted compounds in the spirit; and (5) modification of original spirit congeners in the presence of wood.

The quality of the oak wood and amount of oak wood flavour compounds released from the wood to the distilled liquid during the process of barrel maturation have been shown to vary considerably. This variation has been attributed to various factors. These include differences in oak species and in such geographic factors as country of origin, region, type of forest, climate, soil type, etc. Other factors include inherent variation in composition and characteristics of individual trees (i.e. age, ring width and anatomical composition), part of the tree from which the wood was taken, the method used to obtain the staves, the method (natural or artificial) and length of time that the oak staves are seasoned prior to the barrel being constructed, the time and degree of toasting or heat treatment applied to the finished barrel, the size, shape and prior usage of the barrel, ageing conditions such as the cellar temperature and humidity and spirits maturation time in the barrel, the nature, composition and alcohol concentration of the distillate selected for maturation, and the rate at which such compounds are consumed by further chemical or biochemical transformations (Venter, 1985; Case \& van Wyk, 1989; Hacker, 1991a, b, c; Miller et al., 1992; László, 1995; Canas et al., 1999; Chatonnet, 1999; Peréz-Coello et al., 1999; Sauvageot \& Feuillat, 1999; Vivas, 2000; Cerdán et al., 2002; Smith, 2002; Spillman et al., 2004).

Oak wood is primarily composed of three large insoluble polymers, namely cellulose, hemicellulose and lignin. Cellulose is considered to be the framework of the wood, hemicellulose the matrix, and lignin the encrustant. Oak wood also contains different lower molecular weight compounds, such as volatile and nonvolatile acids, sugars, steroids, terpenes, volatile phenols and lactones. In their natural, unfragmented form, the three major classes of polymers (cellulose, hemicellulose and lignin) are insoluble and can not directly affect flavour. The degradation or compositional changes during the application of coopering heat, and the processes of hydrolysis, alcoholysis or ethanolysis during ageing of hydro-alcoholic solvents in the presence of oak wood, lead to degradation of the wood polymer and the release of different lower molecular weight compounds (Litchev, 1989; Pocock et al., 1994; Conner et al., 1999; Pérez-Coello et al., 1999; Puech et al., 1999). Extracted compounds either are further oxidised into new substances or have immediate potential to affect flavour (Singleton, 1995).

Cis- and trans-oak lactones, two isomers of $\beta$-methyl- $\gamma$ octalactone (also known as whiskey, oak or Quercus lactone), are two of the major volatile and most important aroma compounds present as constituents of oak wood prior to barrel manufacture, which are extracted by brandy during ageing (Suomalainen \& Nykänen, 1972; Suomalainen et al., 1974; Hacker, 1991c; Sefton \& Spillman, 1995; Singleton, 1995). Only 3S,4S (cis) and 3S,4R (trans) $\beta$-methyl- $\gamma$-octalactone are present in oak wood (Masson et al., 1995, 2000). Their concentrations increase considerably during the wood drying/ageing phases of preparation and are also formed during the toasting of barrels through dehydration of lipid ester precursor 2-methyl-3-(3,4-dihydroxy-5-methoxybenzo)octanoic acid present in oak wood (Cerdán et al., 2002). The oak lactone precursor is not stable and hydrolyses during natural seasoning of the oak wood to give rise to the free and more odiferous cis-isomer, which is four times as odiferous as the trans-form (Chatonnet, 1999). Eugenol is present in the wood before toasting (Sefton et al., 1993; Singleton, 1995; Cerdán et al., 2002). Vanillic acid present in brandies is produced by the oxidation of both vanillin and guaiacylpropane units (Canas et al., 1999). The formation of vanillin during toasting is an oxidative, as well as temperature related process (Godden et al., 1999). Vanillin and syringaldehyde are the most abundant forms of phenolic aldehydes from hardwood lignin (Hale et al., 1999). Furfural and 5-hydroxymethyl furfural are products of the thermal degradation of the pentoses moieties of polyose (Singleton, 1995; Hale et al., 1999). Although the phenolic composition of brandy depends primarily on the phenolic composition of the grape, some phenols are extracted from the wood and are referred to as nonflavonoids. These include tannins, hydrolysable tannins, gallic acid, ellagic acid, and aromatic acids and aldehydes (Suomalainen \& Nykänen, 1972; Suomalainen et al., 1974; Jindra \& Gallander, 1987). No aromatic congeners are present in unaged spirits prior to storage in barrels (Baldwin et al., 1967). Steeping of wood in hydro-alcoholic solutions affords the advantage of simulating the extraction conditions which occur during the ageing of spirits.

Since ageing is such an important part of the brandy making process, the optimization of ageing conditions, including the type 
and treatment of raw materials, in order to rapidly induce ageing character, is of particular interest to the brandy industry. The purpose of this study was to investigate the preparation methods and conditions that accompany the use of oak wood extracts to optimise the process of inducing the soft, rounded character which is typical of a good brandy, and to rapidly induce ageing character. This article focuses on the effects of the extraction media (ethanol or water), on the level of concentration (by 45,65 or $85 \%, v / v$ ), and on the type of concentration method employed (open or reduced pressure), on sensory quality and chemical composition of oak extracts, and unmatured pot-still brandy.

Since literature on the composition of oak extracts is limited, and in view of the heterogeneity of such materials and the fact that there are many oak-derived products on the market, extracts should be used for brandy ageing with caution. For these same reasons the extracts used in this work were prepared under known and controlled conditions in the laboratory. By adding to the inventory of oak wood constituents this work contributes to local and international knowledge concerning the applications of wood extracts in brandy aging.

The work reported here was part of a wider investigation of brandy aging. Toasting and type of oak are discussed in separate articles. Interactive aspects of the collected data will be discussed in a subsequent review article.

\section{MATERIALS AND METHODS}

\section{Preparation of oak extracts}

American and French oak chips were obtained from two sources: a cooper and a commercial supplier (Table 1). These sources of oak were used because they are recognised for producing high quality brandy barrels. Toasting levels vary according to supplier or manufacturer specifications, and are not necessarily comparable. Untoasted, medium (toasted at $200^{\circ} \mathrm{C}$ for $120 \mathrm{~min}$ ) and heavy $\left(200^{\circ} \mathrm{C}\right.$ for $\left.150 \mathrm{~min}\right)$ toasted (Table 1) American and French oak chips were obtained from the F. S. Smith \& Co. (Pty) Ltd Coopers, Paarl, South Africa. Seasoning includes initial airdrying in France and a further nine months under South African conditions. Wood was cleaved and treated with ozone water before toasting. Toasting was performed in a McAdams convection oven. Possible differences in materials were minimised by obtaining all of the chips from the same cooper and therefore the same stock of timber, and from the same seasoning and toasting processes. Special (untoasted), premium (medium toasted) and toasted (heavy toasted) American oak chips (Table 1), as well as light, medium and heavy toasted French oak chips (Table 1) were obtained from the commercial supplier African Cork Suppliers (Pty) Ltd.

Chips were added at $200 \mathrm{~g} / \mathrm{L}$ to either $55 \%$ (v/v) (diluted from $96.6 \%$ ) neutral wine spirits, or to distilled water, and distilled. Boiling was carried out under reflux, with backflow cooling using Vigreaux columns and condensers coupled to an ethanol bath at $-10^{\circ} \mathrm{C}$ for five hours, followed by open concentration of the decanted (using a coarse sieve) solvent at atmospheric pressure on a heating mantle in $5 \mathrm{~L}$ round-bottomed flasks. Recorded final temperatures of extracts were $\pm 86^{\circ} \mathrm{C}$ for ethanol, and $\pm 97^{\circ} \mathrm{C}$ for water. Concentration was also carried out under closed conditions (reduced pressure, Table 1) using a Buchi rotavapour (recorded final temperatures of extracts: ethanol $\pm 62^{\circ} \mathrm{C}$ and water $\pm 71^{\circ} \mathrm{C}$; pressure: $\pm 71 \mathrm{kPa}$ ). Heat-extracted solvents were concentrated by $45 \%, 65 \%$ or $85 \%(\mathrm{v} / \mathrm{v})$, relative to the original volume (Table 1). Heating during the distillation and concentration processes also assists with the preliminary degradation of the wood (Puech, 1988). The extracts were fortified to $40 \%(\mathrm{v} / \mathrm{v})$ with $96.6 \%$ wine

\section{TABLE 1}

Experimental layout

\begin{tabular}{|c|c|c|c|c|c|c|c|}
\hline \multirow[t]{4}{*}{ Supplier } & \multirow[t]{4}{*}{ Oak type and toasting level ${ }^{1}$} & \multicolumn{6}{|c|}{ Concentration type, level and medium used } \\
\hline & & \multicolumn{6}{|c|}{ Open $^{2} /$ closed $^{3}$} \\
\hline & & \multicolumn{2}{|c|}{$45 \%{ }^{4}$} & \multicolumn{2}{|c|}{$65 \% \%^{4}$} & \multicolumn{2}{|c|}{$85 \%{ }^{4}$} \\
\hline & & Ethanol $^{5}$ & Water $^{6}$ & Ethanol & Water & Ethanol & Water \\
\hline \multirow[t]{6}{*}{ Cooper } & American oak - untoasted & & & " I & " I & & \\
\hline & American oak - medium $\left(120 \mathrm{~min}\right.$ at $\left.200^{\circ} \mathrm{C}\right)$ & - घ & 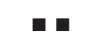 & - घ & - ! & घ & - \\
\hline & American oak - medium + or heavy $\left(150 \mathrm{~min}\right.$ at $\left.200^{\circ} \mathrm{C}\right)$ & & & - घ & 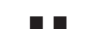 & & \\
\hline & French oak - untoasted & & & - ! & n & & \\
\hline & French oak - medium $\left(120 \mathrm{~min}\right.$ at $\left.200^{\circ} \mathrm{C}\right)$ & - & $\because$ & - घ & 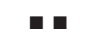 & 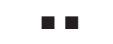 & - \\
\hline & French oak - medium + or heavy $\left(150 \mathrm{~min}\right.$ at $\left.200^{\circ} \mathrm{C}\right)$ & & & 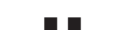 & - & & \\
\hline \multirow[t]{8}{*}{ Commercial supplier } & American: Oak-Mor granular white (Quercus alba) oak & & & & & & \\
\hline & - Special (untoasted) & & & - ! & - घ & & \\
\hline & - Premium (medium toasted) & m & a & m & m & a & " घ \\
\hline & - Toasted (heavy toasted) & & & - - & 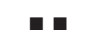 & & \\
\hline & Oak chips: French & & & & & & \\
\hline & - Light & & & " घ & " I & & \\
\hline & - Medium & - I & - I & - I & - I & - I & - I \\
\hline & - Heavy & & & - & m & & \\
\hline
\end{tabular}

${ }^{1}$ Level of toasting as per supplier specifications. ${ }^{2}$ Open concentration of extracts performed in a $5 \mathrm{~L}$ flask on a heating mantle. ${ }^{3} \mathrm{Closed}$ concentration performed under vacuum on a rotavap. ${ }^{4} 45 \%, 65 \%$ and $85 \%(\mathrm{v} / \mathrm{v})$ are the levels to which extracts were concentrated by during preparation. ${ }^{5,6}$ Extractions performed in either ethanol or water medium. Coopering conditions: air dried for nine months under South African conditions prior to initial drying in France, cleaved, ozone treatment before toasting in an oven. 
spirits. Samples of fortified extracts were retained for sensory evaluation. Remaining fortified extracts were added to $67 \%(\mathrm{v} / \mathrm{v})$ unmatured pot-still brandy (procured as one batch) at $60 \mathrm{~mL} / \mathrm{L}$ and stored for eight months in glass containers (Schott bottles) at room temperature, or in the case of controls, below $0^{\circ} \mathrm{C}$. Volumes and weights of all fractions were recorded throughout the extraction procedure.

\section{Sensory evaluation}

Fortified $(40 \%, \mathrm{v} / \mathrm{v})$ extracts representing all treatment combinations were sensorially evaluated in duplicate by a panel of seven judges in different sessions over a period of three days. Acceptability for brandy production was expressed as a yes or no response. The number of yes scores for each extract evaluated was expressed as a percentage of the total number of evaluations per extract. Pot-still brandy samples were also sensorially evaluated (Venter, 1994), in duplicate, for overall quality by a panel of seven experienced judges. A line method was used whereby the value ascribed to each brandy characteristic (herbaceous, fruity, woody, toasted, sweet associated, other positive, other negative and overall quality) was expressed by marking an unstructured, straight $10 \mathrm{~cm}$ line. The left-hand and right-hand ends of the line were, respectively labeled "not detectable" and "prominent".

\section{Determination of volatile components}

Volatile flavour constituents extracted into the distilled spirit from oak chips were separated, identified and quantified by means of gas chromatography (GC), and the non-volatile and less volatile compounds by means of high-performance liquid chromatography (HPLC).

\section{GC determination of oak-derived wood congeners}

Volatile compounds in pot-still brandies were analysed by means of GC, after extraction from pot-still brandy in accordance with Distell Group Limited laboratory methods. Quantification was obtained by calibration with 2-phenylethyl acetate as internal standard. The GC (HP 5890 series II, HP 7673 injector, HP 3396 integrator) conditions were as follows: injection port temperature $200^{\circ} \mathrm{C}$; flame ionisation detector (FID) temperature $250^{\circ} \mathrm{C}$; the oven temperature was programmed from $80^{\circ} \mathrm{C}$ to $210^{\circ} \mathrm{C}$ at $3^{\circ} \mathrm{C} / \mathrm{min}$, and to $230^{\circ} \mathrm{C}$ at $10^{\circ} \mathrm{C} / \mathrm{min}$. The hydrogen flow rate was $30 \mathrm{~mL} / \mathrm{min}$, with a split ratio 20:1. The column was a LabAlliance Polyethylene glycol capillary column ( $60 \mathrm{~m}$ x $0.32 \mathrm{~mm}$ x $0.5 \mu \mathrm{m}$ film thickness). Compounds determined were: Furfural, 5-methylfurfural, guaiacol, eugenol, trans-oak lactone, cis-oak lactone, 2, 6-dimethoxyphenol, 3, 5-hydroxymethyl furfural, vanillin, $o$-cresol, phenol, ethyl guaiacol and $p$-cresol.

\section{HPLC determination of oak-derived wood congeners}

Components were determined and quantified by HPLC, after extraction from pot-still brandy, in accordance with Distell Group Limited laboratory methods, using an external standard calibration method. Chromatographic analyses were carried out using an HPLC (HP 1090 model) with a binary pump and HP Chemstation, thermostatted column compartment, UV Detector $(280 \mathrm{~nm})$ and auto sampler. A reversed-phase column from Phenomenex, Luna $\mathrm{C}_{18} 5 \mathrm{~mm}, 4.6 \times 150 \mathrm{~mm}$, operated at $40^{\circ} \mathrm{C}$, preceded by a security guard holder plus cartridge (Phenomenex), was used. Chromatographic conditions were: Column temperature, $40^{\circ} \mathrm{C}$; flow rate, $1 \mathrm{~mL} / \mathrm{min}$; wavelength, $280 \mathrm{~nm}$; total run time, $55 \mathrm{~min}$. The following compounds were determined: Gallic acid, catechin, vanillic acid, syringic acid, $p$-coumaric acid, syringaldehyde, $m$-coumaric acid, ellagic acid, coniferaldehyde and sinapaldehyde. A stock solution of $1 \mathrm{~g} / \mathrm{L}$ of each of the above-mentioned compounds was made up in methanol and stored at $4^{\circ} \mathrm{C}$. Standard solutions were injected after every 5 samples to confirm the accuracy of the analytical results. The mobile phase included the following: (A), $5 \mathrm{~mL}$ perchloric acid in $1 \mathrm{~L}$ deionised water; and (B), $80 \%$ acetonitrile ( $800 \mathrm{~mL}$ acetonitrile $+200 \mathrm{~mL} \mathrm{~A})$. Samples were prepared by diluting all pot-still brandy samples by addition of $1 \mathrm{~mL}$ of sample to two $\mathrm{mL}$ distilled water and filtering through a $0.45 \mathrm{~mm}$ syringe filter and dispensing $1 \mathrm{~mL}$ of diluted sample into a $1.8 \mathrm{~mL}$ glass vial. A calibration table was also set up.

\section{Statistical Procedures}

The experimental design was completely random with two replicates per treatment. The treatment design was a $2 \times 2 \times 3 \times 2$ x 3 x 2 factorial with factors "agent" (cooper versus commercial supplier), "oak" (American versus French), "level of toasting" (light, medium and heavy), "extraction medium" (ethanol versus water), "concentration level" (45\%, 65\% and 85\%, v/v), “open/ vacuum" (open versus reduced-pressure), resulting in a total of 144 treatment combinations. As toasting for the different agent $\mathrm{x}$ oak combinations may not be comparable, the agent $\mathrm{x}$ oak $\mathrm{x}$ toasting level combinations should rather be considered as 12 different sources of oak. However, those wood extracts that proved on preliminary sensory evaluation to have a burnt character (generally representative of the highest or $85 \%$, v/v concentration level), and those that were derived from wood that was more coarsely granular than chip-sized were rejected. Only 80 of the 144 treatment combinations were therefore tested. Analyses were performed in groups, each containing a complete set of treatment combinations for specific factorial combinations. The 80 treatment combinations tested included only the "medium" toasting levels for the $45 \%$ and $85 \%$ concentration levels. Thus for the first analysis only data for the $65 \%$ concentration was included to obtain a complete set of data over the 12 agent $\mathrm{x}$ oak $\mathrm{x}$ toasting level combinations, resulting in a complete 12 x 2 x 2 (12 oak sources x open/close x ethanol/ water) factorial analysis. For the second analysis only data for medium toasting was included to obtain a complete set of data over concentration level, resulting in a 4 × 2 × 3 × 2 (4 "medium" toasted oak sources $\mathrm{x}$ open/close $\mathrm{x} 3$ concentration levels $\mathrm{x}$ ethanol/water) factorial analysis (only relevant to the sensory and GC variables for unmatured pot-still brandy).

The variables measured were subjected to Analysis of Variance (ANOVA), using GLM (General Linear Models) procedure of SAS statistical software version 8.2 (SAS Institute Inc., Cary, NC, USA) (SAS, 2000). The Shapiro-Wilk test was performed to test for normality (Shapiro \& Wilk, 1965). Fisher's t-least significant difference (LSD) was calculated at the $5 \%$ probability level to facilitate comparison between treatment means.

Since not all of the 23 volatile and non-volatile components necessarily serve as classifiers, an initial univariate analysis was conducted to identify which species would have the greatest discriminating power. Multivariate analysis of variance (MANOVA) was also performed at the 95\% confidence level. Discriminant analysis (DA) was used as the pattern recognition tool, using the full dataset or dataset comprising the $65 \%(\mathrm{v} / \mathrm{v})$ concentration level. Based on the fact that selection of key features among the chemical data set may offer an increased 


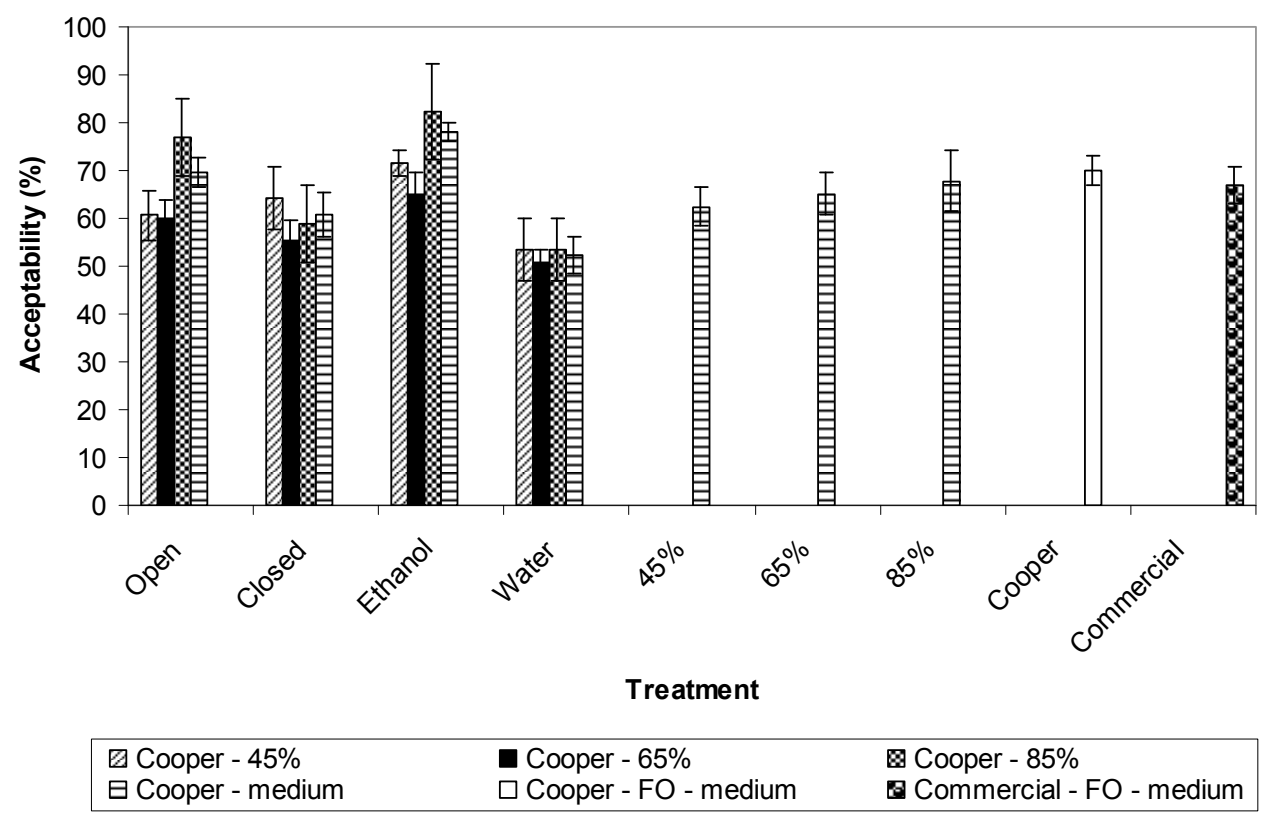

FIGURE 1

Percentage sensory acceptability of oak extracts prepared from chips of different types of differently toasted oak obtained from a cooper and commercial supplier, and subjected to various treatments. Open concentration of extracts performed in $5 \mathrm{~L}$ flask on a heating mantle. Closed concentration performed under vacuum on a rotavap. Extractions performed in either water or ethanol medium. Extracts concentrated by $45 \%, 65 \%$ or $85 \%$ (v/v) of original volume. Legends, i.e. cooper $45 \%$, indicate the group subjected to statistical treatment, i.e. only cooper and the $45 \%(\mathrm{v} / \mathrm{v})$ concentration level. Error bars represent the standard error of the mean.

reliability of the mathematical outcome, discriminant analysis by the forward stepwise method was used to select the most powerful discriminators or variables most effective at separating the factors. The ellipses around each grouping represent the $95 \%$ confidence limit for that grouping. All computations were carried out with the package XLSTAT 2008 [Pro] (Win).

\section{RESULTS AND DISCUSSION}

The rationale on which the extraction procedure was based, took several factors into account. In this study chips were added to spirits at $200 \mathrm{~g} / \mathrm{L}$. Concentrations of up to $500 \mathrm{mg} / \mathrm{L}$, four times the threshold of $2 \mathrm{~g} / \mathrm{L}, 1-10 \mathrm{~g} / \mathrm{L}, 0.2-0.9 \mathrm{~g} / \mathrm{L}$ and $2 \%$ or $2 \mathrm{~g} / 100$ $\mathrm{mL}$ for alcoholic beverages were either used, are recommended, or required (Singleton, 1974, 1995; Giménez Martínez et al., 2001).

Extraction of components is enhanced with chips because of the larger surface to volume ratio. Giménez Martínez et al. (2001) found maximum extraction of phenolic compounds with chip sizes ranging from 3-7 mm, similar to the chip size used in this study (except for Oak-Mor granular white oak).

Two solvents were selected for the purpose of this study, i.e. ethanol and water. Wine/water/spirits/hydro-alcoholic extracts act as solvents in the extraction of polymers (lignins, polysaccharides) during ageing. Spirits, in contrast to wines, damage the cellular structure of woody tissues (Vivas \& Saint-Cricq de Gaulejac, 1999).

In this study a $55 \%(\mathrm{v} / \mathrm{v})$ ethanol concentration was chosen for extraction purposes for various reasons based on reported solids extractability/solubility and optimum quality (Singleton \& Draper, 1961; Guymon \& Crowell, 1970; Venkataramu et al., 1983; Puech, 1984; Venter, 1985; Puech, 1987; Singleton, 1995; Giménez Martínez et al., 2001).
Because of its decisive influence on the concentration of compounds, and to achieve optimum extraction of wood aromatic compounds, heating times for oak wood that are in excess of 3-6 hours at $185^{\circ} \mathrm{C}$ are not recommended (Giménez Martínez et al., 2001). Heating times of 120 (medium toast) and 150 minutes (heavy toast) at $200^{\circ} \mathrm{C}$ were used by the cooper in this study. In the absence of prior specifications, and of the variable concentrations used by different suppliers / producers, concentrations of $45 \%$, $65 \%$ and $85 \%(\mathrm{v} / \mathrm{v})$ were selected for this work.

The significance of the effects of the different treatments and their interactions were determined from the analysis of variance (ANOVA). Results for the treatments concentration type (open vs. closed), concentration level ( $45 \%$ vs. $65 \%$ vs. $85 \%$, v/v), extraction medium (ethanol vs. water) and supplier (cooper vs. commercial) are given in Tables 2-10. Multivariate analysis of variance (MANOVA) was also performed at the $95 \%$ confidence level. A discriminant analysis technique was applied to better classify samples using a chosen set of variables. Because the number of extractions performed, their sensory evaluations, the number of components analysed by GC and HPLC, and the number of treatment combinations were large, too many results were obtained for a fully inclusive account to be presented here. Representative data are presented in Figures 1-5 and Tables 2-10.

\section{Level of concentration}

\section{Extracts}

Sensory evaluation (for acceptability only) of fortified oak extracts showed, for both commercial (result not shown) and specially prepared wood chips from a cooper (Fig. 1), that extracts concentrated by $85 \%$ were generally more acceptable to the panel than those concentrated by $45 \%$ and $65 \%(\mathrm{v} / \mathrm{v})$, with $65 \%(\mathrm{v} / \mathrm{v})$ generally being slightly more acceptable than $45 \%(\mathrm{v} / \mathrm{v})$. 


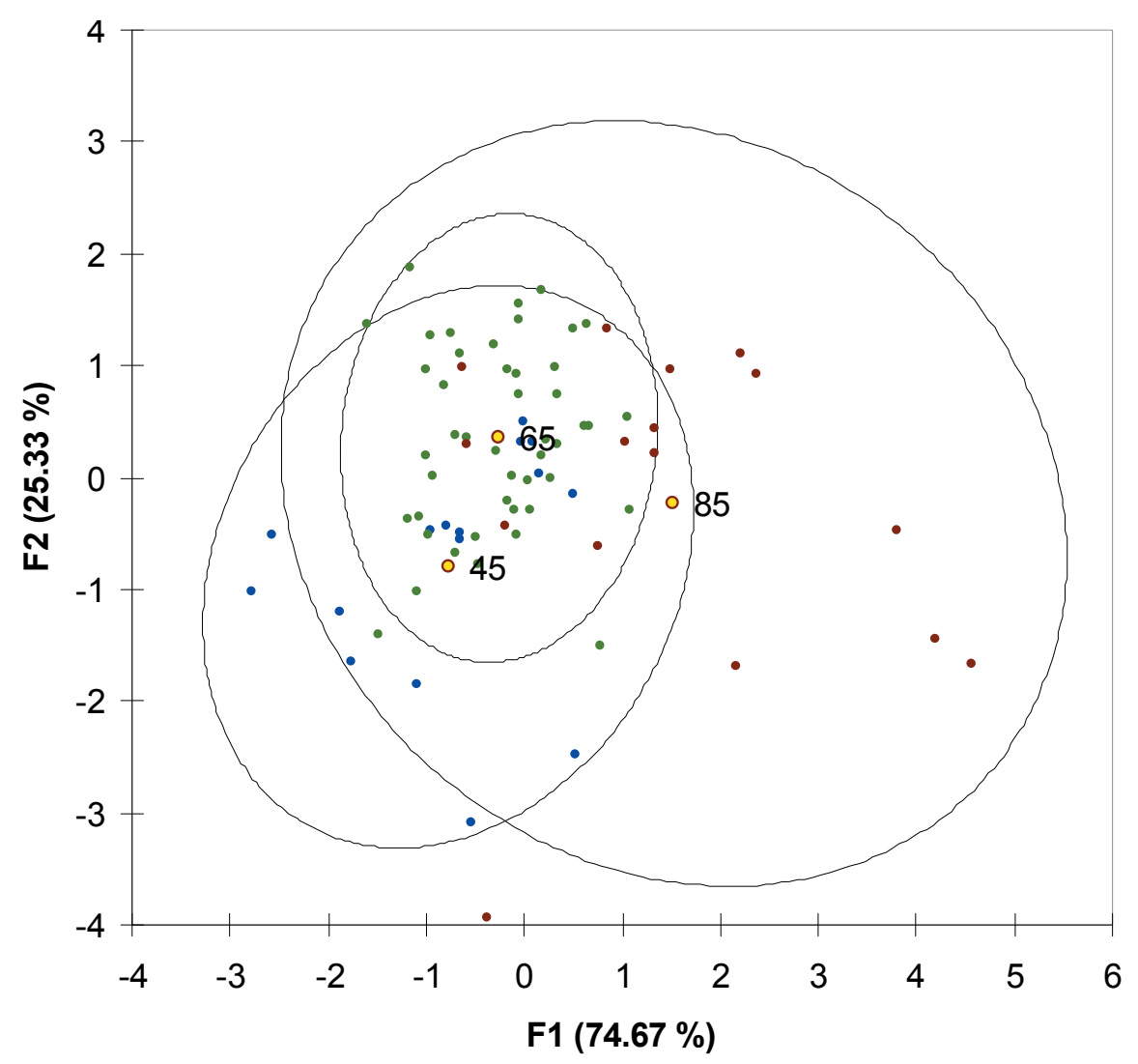

$\cdot 45 \cdot 65 \cdot 85 \circ$ Centroids

FIGURE 2

Plots of discriminant function scores of the first two discriminant factors (F1, F2) for the treatment classes $45 \%, 65 \%$ and $85 \%$, computed using the variables percent acceptability, furfural, 5-methylfurfural, guaiacol, cis-oak lactone, trans-oak lactone, eugenol, 2,6-dimethoxyphenol, 5-hydroxymethyl furfural and vanillin. Unmatured pot-still brandies were prepared with oak wood extracts prepared from chips of different types of differently toasted oak obtained from a cooper and commercial supplier and subjected to various treatments as described in the legend to Fig. 1.

\section{Unmatured pot-still brandy}

Higher levels of concentration, i.e. $85 \%$ as opposed to $65 \%$ as opposed to $45 \%(\mathrm{v} / \mathrm{v})$, yielded higher $(\mathrm{p} \leq 0.05)$ concentrations of the volatile wood-derived congeners eugenol and 5-hydroxymethyl furfural in unmatured pot-still brandy (Table 2).

Minimal separation of the three groups of samples, i.e. $45 \%$, $65 \%$ and $85 \%$ was achieved using DA (Fig. 2).

Variation in the data may be attributed to factors that impact on the type and amount of compounds extracted from the wood. In addition to factors such as the origin and condition of the wood, type of oak, techniques of wood preparation and fabrication, seasoning treatment/location, coopering techniques and processes, and physical or chemical treatment of the wood, extraction conditions, including the medium and heat sources used, are known to impact on the type and amount of compounds extracted from the wood (Guymon \& Crowell, 1970; Puech, 1987, 1988; Francis et al., 1992; Sefton \& Spillman, 1995).

\section{Cooper versus commercial}

\section{Extracts}

Fortified extracts were subjected to sensory evaluation for acceptability purposes. Panelists found only minor differences between fortified extracts prepared from oak chips from a cooper and those from a commercial supplier. Overall, they slightly favored extracts that were prepared with chips obtained from a cooper (Fig. 1).

\section{Unmatured pot-still brandy}

Pot-still brandies prepared with extracts of oak chips obtained from a cooper yielded higher $(\mathrm{p} \leq 0.05)$ concentrations of the volatile congener 5-methylfurfural than pot-still brandies prepared from commercially obtained chips (Table 3 ). In contrast, pot-still brandies prepared with extracts of oak chips from commercial suppliers, contained higher $(\mathrm{p} \leq 0.05)$ concentrations of the lessvolatile congeners catechin, and vanillic and syringic acids than was the case in pot-still brandies prepared using chips from a cooper (Table 4).

\section{Eight-month matured pot-still brandy}

Panelists detected little difference in sensory quality $(\mathrm{p} \geq 0.05)$ between eight-month matured pot-still brandies prepared with extracts from oak chips obtained from a cooper and from a commercial supplier. As was the case for fortified extracts, matured pot-still brandy samples prepared with extracts from cooperageobtained chips were slightly favored by the panelists (Fig. 3). Similar to unmatured pot-still brandy samples, eight-month matured pot-still brandy samples prepared with extracts from chips obtained from a cooper, contained higher $(p \leq 0.05)$ concentrations 
TABLE 2

Gas chromatographic analysis of unmatured pot-still brandy prepared from oak (cooper only) extracts.

\begin{tabular}{|c|c|c|c|c|c|c|c|c|c|}
\hline \multirow[t]{2}{*}{ Type/ Treatment } & \multirow[t]{2}{*}{ n* } & \multicolumn{8}{|c|}{ Mean (mg/L) } \\
\hline & & Furfural & $\begin{array}{l}\text { 5-Methyl- } \\
\text { furfural }\end{array}$ & Guaiacol & $\begin{array}{c}\text { trans-oak } \\
\text { Lactone }\end{array}$ & $\begin{array}{c}\text { cis-oak } \\
\text { Lactone }\end{array}$ & $o$-Cresol & Phenol & $\begin{array}{c}\text { Ethyl } \\
\text { guaiacol }\end{array}$ \\
\hline $45 \%$ & 10 & $\begin{array}{c}29.512^{\mathrm{a}} \\
(4.850)^{* *}\end{array}$ & $\begin{array}{l}2.041^{\mathrm{a}} \\
(0.575)\end{array}$ & $\begin{array}{c}1.075^{\mathrm{a}} \\
(0.196)\end{array}$ & $\mathrm{nd}^{* * *}$ & $\begin{array}{c}0.068^{\mathrm{b}} \\
(0.068)\end{array}$ & nd & nd & nd \\
\hline $65 \%$ & 12 & $\begin{array}{l}28.294^{\mathrm{a}} \\
(3.620)\end{array}$ & $\begin{array}{c}1.284^{b} \\
(0.403)\end{array}$ & $\begin{array}{c}1.114^{\mathrm{a}} \\
(0.187)\end{array}$ & nd & $\begin{array}{c}0.078^{\mathrm{a}} \\
(0.053)\end{array}$ & nd & nd & nd \\
\hline $85 \%$ & 10 & $\begin{array}{l}18.995^{\mathrm{a}} \\
(3.286)\end{array}$ & $\begin{array}{c}0.272^{\mathrm{c}} \\
(0.120)\end{array}$ & $\begin{array}{c}1.141^{\mathrm{a}} \\
(0.200)\end{array}$ & nd & $\begin{array}{c}0.000^{c} \\
(0.000)\end{array}$ & nd & nd & nd \\
\hline
\end{tabular}

\begin{tabular}{|c|c|c|c|c|c|c|}
\hline \multirow[t]{2}{*}{ Type/ Treatment } & \multirow[t]{2}{*}{$\mathbf{n}$} & \multicolumn{5}{|c|}{ Mean (mg/L) } \\
\hline & & $p$-Cresol & Eugenol & $\begin{array}{c}\text { 2,6-Dimethoxy- } \\
\text { phenol }\end{array}$ & $\begin{array}{c}\text { 5-Hydroxymethyl } \\
\text { furfural }\end{array}$ & Vanillin \\
\hline $45 \%$ & 10 & nd & $\begin{array}{l}0.013^{\mathrm{b}} \\
(0.013)\end{array}$ & $\begin{array}{l}30.157^{\mathrm{a}} \\
(1.812)\end{array}$ & $\begin{array}{l}3.925^{\mathrm{b}} \\
(0.730)\end{array}$ & $\begin{array}{l}8.641^{\mathrm{a}} \\
(6.048)\end{array}$ \\
\hline $65 \%$ & 12 & nd & $\begin{array}{c}0.000^{\mathrm{c}} \\
(0.000)\end{array}$ & $\begin{array}{l}31.664^{\mathrm{a}} \\
(1.373)\end{array}$ & $\begin{array}{l}7.945^{\mathrm{ab}} \\
(1.677)\end{array}$ & $\begin{array}{l}6.764^{\mathrm{a}} \\
(3.622)\end{array}$ \\
\hline $85 \%$ & 10 & nd & $\begin{array}{l}0.151^{\mathrm{a}} \\
(0.083)\end{array}$ & $\begin{array}{l}32.954^{\mathrm{a}} \\
(1.223)\end{array}$ & $\begin{array}{l}11.563^{\mathrm{a}} \\
(1.272)\end{array}$ & $\begin{array}{l}5.846^{\mathrm{a}} \\
(0.505)\end{array}$ \\
\hline
\end{tabular}

*, Number of evaluations of samples; $* *$, standard error of the mean; ***, not detected. Treatments with the same superscript within columns do not differ significantly $(\mathrm{p} \leq 0.05)$. Forty five percent, $65 \%$ and $85 \%(\mathrm{v} / \mathrm{v})$ are the levels by which extracts were concentrated during preparation. Data representative of the medium toast.

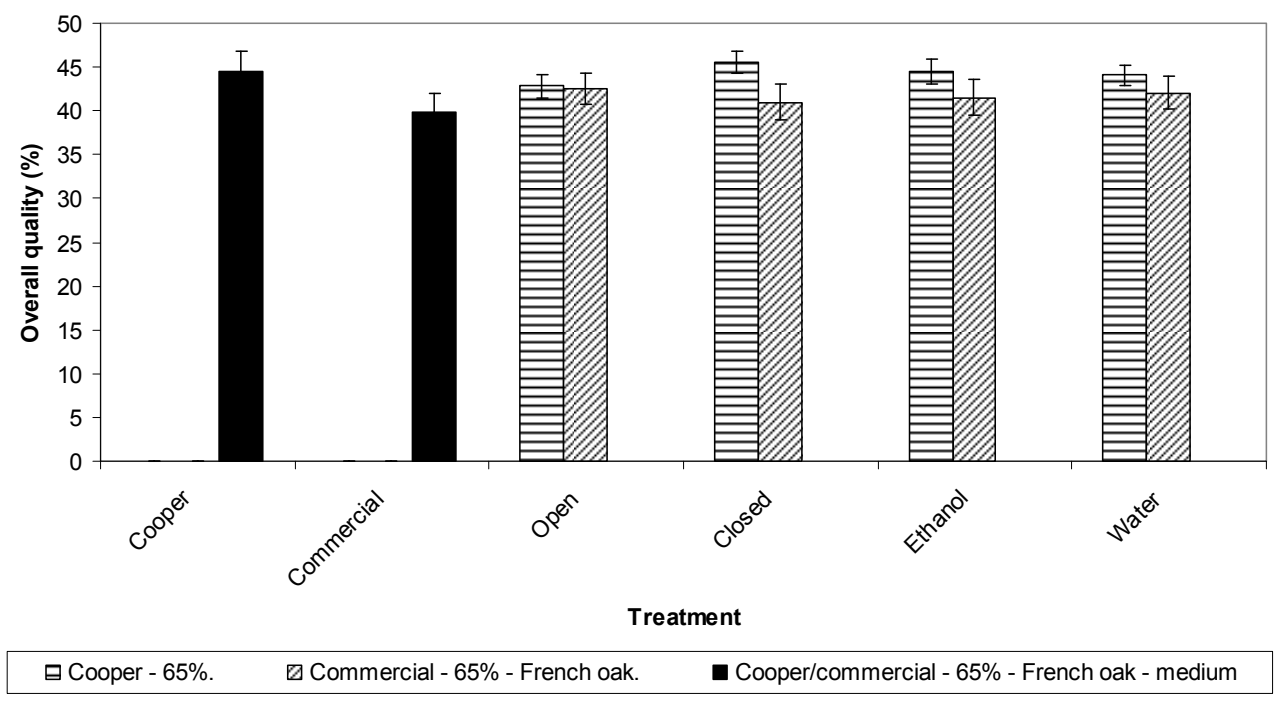

FIGURE 3

Overall sensory quality of eight-month matured pot-still brandy from oak extracts prepared from chips of different types of differently toasted oak obtained from a cooper and commercial suppliers, subjected to various treatments and stored at room temperature or below $0{ }^{\circ} \mathrm{C}$. Open concentration of extracts performed in a $5 \mathrm{~L}$ flask on a heating mantle. Closed concentration performed under vacuum on a rotavap. Extractions performed in either water or ethanol medium. Only $65 \%$ (v/v) concentration was considered in the statistical evaluation. Legends, i.e. commercial - 65\% - French oak, indicate the group subjected to statistical treatment, i.e. only commercial French oak samples and the $65 \%(\mathrm{v} / \mathrm{v})$ concentration level. Error bars represent the standard error of the mean.

of the volatile compounds / congeners 5-methylfurfural, as well as furfural, 2,6-dimethoxyphenol and 5-hydroxymethylfurfural (Table 5), but lower concentrations of less volatile (Table 6) wood-derived congeners protocatechuic acid, catechin, syringic acid, syringaldehyde and coniferaldehyde than those prepared using chips obtained from commercial suppliers. Significant differences were, therefore, observed in concentrations of the aromatic aldehydes vanillin (matured and unmatured samples), syringaldehyde (matured and unmatured), coniferaldehyde (matured) and sinapaldehyde (matured) in samples prepared from 
TABLE 3

Concentration of gas chromatographic determined oak congeners in unmatured pot-still brandy prepared with extracts from oak chips obtained from a cooper and commercial suppliers and subjected to various treatments.

\begin{tabular}{|c|c|c|c|c|c|c|c|c|}
\hline \multirow[t]{2}{*}{ Type/Treatment } & \multirow[t]{2}{*}{$\mathbf{n}^{*}$} & \multicolumn{7}{|c|}{ Mean (mg/L) } \\
\hline & & Furfural & $\begin{array}{l}\text { 5-Methyl- } \\
\text { furfural }\end{array}$ & Guaiacol & $\begin{array}{l}\text { trans-oak } \\
\text { Lactone }\end{array}$ & $\begin{array}{l}\text { cis-oak } \\
\text { Lactone }\end{array}$ & $o$-Cresol & Phenol \\
\hline Cooper & 8 & $\begin{array}{c}32.833^{\mathrm{a}} \\
(4.373)^{* *}\end{array}$ & $\begin{array}{r}1.345^{\mathrm{a}} \\
(0.534)\end{array}$ & $\begin{array}{l}1.155^{\mathrm{a}} \\
(0.233)\end{array}$ & $\mathrm{nd}^{* * *}$ & nd & nd & nd \\
\hline $\begin{array}{l}\text { Commercial } \\
\text { supplier }\end{array}$ & 4 & $\begin{array}{l}15.703^{\mathrm{a}} \\
(1.058)\end{array}$ & $\begin{array}{c}0.158^{\mathrm{b}} \\
(0.158)\end{array}$ & $\begin{array}{l}1.971^{\mathrm{a}} \\
(0.623)\end{array}$ & nd & nd & nd & nd \\
\hline
\end{tabular}

\begin{tabular}{|c|c|c|c|c|c|c|c|}
\hline \multirow[t]{2}{*}{ Type/Treatment } & \multirow[t]{2}{*}{$\mathbf{n}$} & \multicolumn{6}{|c|}{ Mean $(\mathrm{mg} / \mathrm{L})$} \\
\hline & & Ethyl guaiacol & $p$-Cresol & Eugenol & $\begin{array}{c}\text { 2,6-Dimethoxy- } \\
\text { phenol }\end{array}$ & $\begin{array}{l}\text { 5-Hydroxymethyl } \\
\text { furfural }\end{array}$ & Vanillin \\
\hline Cooper & 8 & nd & nd & nd & $\begin{array}{l}32.841^{\mathrm{a}} \\
(1.558)\end{array}$ & $\begin{array}{l}9.844^{\mathrm{a}} \\
(2.218)\end{array}$ & $\begin{array}{l}3.284^{\mathrm{b}} \\
(0.506)\end{array}$ \\
\hline $\begin{array}{l}\text { Commercial } \\
\text { supplier }\end{array}$ & 4 & nd & nd & nd & $\begin{array}{l}28.930^{\mathrm{a}} \\
(0.864)\end{array}$ & $\begin{array}{r}3.174^{\mathrm{a}} \\
(0.311)\end{array}$ & $\begin{array}{l}5.722^{\mathrm{a}} \\
(0.672)\end{array}$ \\
\hline
\end{tabular}

*, Number of evaluations of samples; **, standard error of the mean; ***, not detected. Treatments with the same superscript within columns do not differ significantly $(\mathrm{p} \geq 0.05)$. Data representative of French oak extracts of medium toast concentrated by $65 \%(\mathrm{v} / \mathrm{v})$.

oak chips obtained from a cooper and a commercial supplier, respectively (Tables 3 to 6). Puech (1988) also reported differences in concentration in these phenolic compounds between different preparations, i.e. liquid and powder extracts and Armagnac traditionally aged in oak barrels.

In this study the observed differences between eight-month matured pot-still brandies prepared from chips obtained from a cooper and from commercial suppliers probably reflect the impact or influence of different factors such as oak origin, seasoning and coopering methods on the composition and concentration of compounds which affected the sensory quality of pot-still brandy. Different physical or chemical treatments used by manufacturers in the production of oak wood extracts are also known to impact on results (Puech, 1988).

\section{Ethanol versus water medium}

\section{Extracts}

Both water and ethanol extracts of oak contain colouring agents, some carbohydrate derivatives, gallo- and ellagitannins, lignin fragments, and their precursor/degradation products. The extracts also add flavour to the final product (Singleton, 1995). For both commercially and specially prepared chips from a cooper, extracts prepared in ethanol medium were more acceptable sensorially than those prepared using water as extraction medium (Fig. 1).

\section{Unmatured pot-still brandy}

Generally, for detectable oak-derived congeners, the use of ethanol as extraction medium during the preparation of extracts yielded higher concentrations of most volatile compounds in unmatured pot-still brandy than the use of water as extraction medium (Table 7). The concentrations of less volatile wood-derived congeners (gallic acid, catechin, $p$-coumaric acid, $m$-coumaric acid) in unmatured pot-still brandy, prepared with extracts from oak chips using ethanol as extraction medium, tended to be slightly or significantly $(\mathrm{p} \leq 0.05)$ higher than those prepared in water medium (Table 8). Fluctuating concentrations for vanillin $(4.75$ to $7.11 \mathrm{mg} / \mathrm{L})$, syringaldehyde (9.42 to $17.26 \mathrm{mg} / \mathrm{L})$ and gallic acid $(0.44$ to $1.63 \mathrm{mg} / \mathrm{L})$ in spirits macerated with American oak chips ( $2 \mathrm{~g} / \mathrm{L} 55^{\circ}$ proof ethyl alcohol) and diluted to $40^{\circ}$, have been reported by Giménez Martínez et al. (2001). In this study, concentrations of 0 to $7.58 \mathrm{mg} / \mathrm{L}, 0$ to $24.52 \mathrm{mg} / \mathrm{L}$ and 0.71 to $14.4 \mathrm{mg} / \mathrm{L}$, respectively, were found for unmatured pot-still brandy prepared with American oak chips.

\section{Eight-month matured pot-still brandy}

Eight-month matured pot-still brandy, prepared with extracts from chips obtained from a cooper and using an ethanol medium, were more acceptable $(\mathrm{p} \geq 0.05)$ sensorially than those prepared using water as extraction medium (Fig. 3). In the case of commercial samples, eight-month matured pot-still brandy prepared with extracts using a water medium was equally acceptable to that prepared using ethanol (Fig. 3). Previous studies conducted at ARC Infruitec-Nietvoorbij also found the colour acceptance and ageing character of ethanol extracts to be superior to those of water extracts after eight months of maturation. Although the colour acceptance improved further from eight to sixteen months maturation, the ageing character decreased somewhat over the same period in ethanol extracts. Data obtained from these previous studies confirm that treatment of the wood (i.e. seasoning and toasting), the procedures used for the preparation of extracts, and storage conditions, all have remarkable effects on the composition and concentration of individual aroma compounds.

The concentrations of the volatile wood-derived congeners in eight-month matured pot-still brandy prepared with oak extracts 
TABLE 4

Concentration of high-performance liquid chromatographic determined oak congeners in unmatured pot-still brandy prepared with extracts from oak chips obtained from a cooper and commercial suppliers.

\begin{tabular}{|c|c|c|c|c|c|c|}
\hline \multirow[t]{2}{*}{ Type/Treatment } & \multirow[t]{2}{*}{$\mathbf{n}^{*}$} & \multicolumn{5}{|c|}{ Mean (mg/L) } \\
\hline & & Gallic acid & Catechin & Vanillic acid & Syringic acid & $p$-Coumaric acid \\
\hline Cooper & 8 & $\begin{array}{c}8.073^{\mathrm{a}} \\
(0.853)^{* *}\end{array}$ & $\begin{array}{c}1.593^{\mathrm{b}} \\
(0.798)\end{array}$ & $\begin{array}{c}1.833^{\mathrm{b}} \\
(0.304)\end{array}$ & $\begin{array}{c}4.060^{\mathrm{b}} \\
(0.605)\end{array}$ & $\begin{array}{c}0.514^{\mathrm{a}} \\
(0.229)\end{array}$ \\
\hline $\begin{array}{l}\text { Commercial } \\
\text { supplier }\end{array}$ & 4 & $\begin{array}{c}6.600^{\mathrm{a}} \\
(0.926)\end{array}$ & $\begin{array}{c}9.060^{\mathrm{a}} \\
(1.785)\end{array}$ & $\begin{array}{c}3.283^{\mathrm{a}} \\
(1.230)\end{array}$ & $\begin{array}{c}5.813^{\mathrm{a}} \\
(1.206)\end{array}$ & $\begin{array}{c}0.613^{\mathrm{a}} \\
(0.526)\end{array}$ \\
\hline \multirow[t]{2}{*}{ Type/Treatment } & $\mathbf{n}$ & \multicolumn{5}{|c|}{ Mean (mg/L) } \\
\hline & & Syringaldehyde & $m$-Coumaric acid & Ellagic acid & Coniferaldehyde & Sinapaldehyde \\
\hline Cooper & 8 & $\begin{array}{c}6.986^{\mathrm{b}} \\
(1.357)\end{array}$ & $\begin{array}{c}0.126^{\mathrm{a}} \\
(0.073)\end{array}$ & $\begin{array}{c}50.730^{\mathrm{a}} \\
(12.956)\end{array}$ & $\begin{array}{l}10.694^{\mathrm{a}} \\
(2.277)\end{array}$ & $\begin{array}{l}38.364^{\mathrm{a}} \\
(8.812)\end{array}$ \\
\hline $\begin{array}{l}\text { Commercial } \\
\text { supplier }\end{array}$ & 4 & $\begin{array}{l}22.568^{\mathrm{a}} \\
(5.765)\end{array}$ & $\begin{array}{c}0.443^{\mathrm{a}} \\
(0.187)\end{array}$ & $\begin{array}{c}69.063^{\mathrm{a}} \\
(31.625)\end{array}$ & $\begin{array}{l}8.540^{\mathrm{a}} \\
(2.961)\end{array}$ & $\begin{array}{l}29.940^{\mathrm{a}} \\
(9.792)\end{array}$ \\
\hline
\end{tabular}

*, Number of evaluations of samples; **, standard error of the mean. Treatments with the same superscript within columns do not differ significantly ( $\mathrm{p} \geq 0.05$ ). Data representative of French oak chips of medium toast concentrated by $65 \%(\mathrm{v} / \mathrm{v})$.

\section{TABLE 5}

Concentration of gas chromatographic determined oak congeners in eight month matured pot-still brandy prepared with extracts from oak chips obtained from a cooper and commercial suppliers.

\begin{tabular}{|c|c|c|c|c|c|c|c|c|}
\hline \multirow[t]{2}{*}{ Type/Treatment } & \multirow[t]{2}{*}{$\mathbf{n}^{*}$} & \multicolumn{7}{|c|}{ Mean (mg/L) } \\
\hline & & Furfural & $\begin{array}{l}\text { 5-Methyl- } \\
\text { furfural }\end{array}$ & Guaiacol & $\begin{array}{l}\text { trans-oak } \\
\text { Lactone }\end{array}$ & $\begin{array}{c}\text { cis-oak } \\
\text { Lactone }\end{array}$ & $o$-Cresol & Phenol \\
\hline Cooper & 16 & $\begin{array}{c}27.956^{\mathrm{a}} \\
(3.557)^{* *}\end{array}$ & $\begin{array}{c}1.718^{\mathrm{a}} \\
(0.449)\end{array}$ & $\begin{array}{c}0.576^{\mathrm{a}} \\
(0.075)\end{array}$ & $\begin{array}{c}0.000^{\mathrm{a}} \\
(0.000)\end{array}$ & $\begin{array}{c}0.000^{\mathrm{a}} \\
(0.000)\end{array}$ & $\mathrm{nd}^{* * *}$ & nd \\
\hline $\begin{array}{l}\text { Commercial } \\
\text { supplier }\end{array}$ & 16 & $\begin{array}{l}16.829^{b} \\
(0.644)\end{array}$ & $\begin{array}{l}0.521^{\mathrm{b}} \\
(0.139)\end{array}$ & $\begin{array}{c}0.535^{\mathrm{a}} \\
(0.068)\end{array}$ & $\begin{array}{l}0.146^{\mathrm{a}} \\
(0.102)\end{array}$ & $\begin{array}{c}0.104^{\mathrm{a}} \\
(0.104)\end{array}$ & nd & nd \\
\hline
\end{tabular}

\begin{tabular}{|c|c|c|c|c|c|c|c|}
\hline \multirow[t]{2}{*}{ Type/Treatment } & \multirow[t]{2}{*}{$\mathbf{n}$} & \multicolumn{6}{|c|}{ Mean (mg/L) } \\
\hline & & Ethyl guaiacol & $p$-Cresol & Eugenol & $\begin{array}{c}\text { 2,6-Dimethoxy- } \\
\text { phenol }\end{array}$ & $\begin{array}{l}\text { 5-Hydroxymethyl } \\
\text { furfural }\end{array}$ & Vanillin \\
\hline Cooper & 16 & $\begin{array}{c}2.638^{a} \\
(0.064)\end{array}$ & nd & $\begin{array}{c}0.218^{\mathrm{a}} \\
(0.056)\end{array}$ & $\begin{array}{l}37.228^{\mathrm{a}} \\
(0.900)\end{array}$ & $\begin{array}{c}6.742^{\mathrm{a}} \\
(0.476)\end{array}$ & $\begin{array}{c}4.454^{\mathrm{b}} \\
(0.466)\end{array}$ \\
\hline $\begin{array}{l}\text { Commercial } \\
\text { supplier }\end{array}$ & 16 & $\begin{array}{l}2.466^{\mathrm{a}} \\
(0.107)\end{array}$ & nd & $\begin{array}{r}0.221^{\mathrm{a}} \\
(0.069)\end{array}$ & $\begin{array}{l}35.748^{\mathrm{b}} \\
(0.869)\end{array}$ & $\begin{array}{l}5.743^{\mathrm{b}} \\
(0.419)\end{array}$ & $\begin{array}{l}8.166^{\mathrm{a}} \\
(0.920)\end{array}$ \\
\hline
\end{tabular}

*, Number of evaluations of samples; **, standard error of the mean; ***, not detected. Treatments with the same superscript within columns do not differ significantly $(\mathrm{p} \geq 0.05)$. Data representative of French oak extracts of medium toast concentrated by $65 \%(\mathrm{v} / \mathrm{v})$.

using ethanol as extraction medium were generally higher than where water had been used as the extraction medium (Table 9). The concentrations of the less volatile wood-derived congeners in eight-month matured pot-still brandy prepared with oak extracts that used ethanol as extraction medium were generally higher than those prepared using water as extraction medium (Table 10).
The improvement in sensory quality and the concentration of extractables in ethanol medium correlates with findings of other authors (Baldwin et al., 1967; Singleton, 1974; Puech, 1987). High-alcohol beverages such as brandy are therefore likely to extract more flavour from wood than wine or other low alcohol beverages (Singleton, 1974). Singleton (1995) stated that ethanol 


\section{TABLE 6}

Concentration of high-performance liquid chromatographic determined oak congeners in eight month matured pot-still brandy prepared with extracts from oak chips obtained from a cooper and commercial suppliers.

\begin{tabular}{|c|c|c|c|c|c|c|c|}
\hline \multirow[t]{2}{*}{ Type/Treatment } & \multirow[t]{2}{*}{$\mathrm{n}^{*}$} & \multicolumn{6}{|c|}{ Mean $(\mathrm{mg} / \mathrm{L})$} \\
\hline & & Gallic acid & $\begin{array}{c}\text { Protocatachuic } \\
\text { acid }\end{array}$ & $\begin{array}{l}p \text {-Hydroxy- } \\
\text { benzoic acid }\end{array}$ & Catechin & Vanillic acid & Syringic acid \\
\hline Cooper & 48 & $\begin{array}{c}7.714^{\mathrm{a}} \\
(0.587)^{* *}\end{array}$ & $\begin{array}{c}0.588^{\mathrm{b}} \\
(0.266)\end{array}$ & $\begin{array}{c}0.369^{\mathrm{a}} \\
(0.168)\end{array}$ & $\begin{array}{c}0.000^{\mathrm{b}} \\
(0.000)\end{array}$ & $\begin{array}{c}1.246^{\mathrm{a}} \\
(0.117)\end{array}$ & $\begin{array}{c}3.529^{\mathrm{b}} \\
(0.444)\end{array}$ \\
\hline $\begin{array}{l}\text { Commercial } \\
\text { supplier }\end{array}$ & 42 & $\begin{array}{c}6.131^{\mathrm{b}} \\
(0.418)\end{array}$ & $\begin{array}{c}0.864^{\mathrm{a}} \\
(0.395)\end{array}$ & $\begin{array}{c}0.404^{\mathrm{a}} \\
(0.218)\end{array}$ & $\begin{array}{c}2.862^{\mathrm{a}} \\
(1.002)\end{array}$ & $\begin{array}{c}1.230^{\mathrm{a}} \\
(0.303)\end{array}$ & $\begin{array}{l}5.775^{\mathrm{a}} \\
(0.629)\end{array}$ \\
\hline \multirow[t]{2}{*}{ Type/Treatment } & $\mathbf{n}$ & \multicolumn{6}{|c|}{ Mean (mg/L) } \\
\hline & & $p$-Coumaric acid & Syringaldehyde & $m$-Coumaric acid & Ellagic acid & Coniferaldehyde & Sinapaldehyde \\
\hline Cooper & 48 & $\mathrm{nd} * * *$ & $\begin{array}{l}13.231^{\mathrm{b}} \\
(1.514)\end{array}$ & $\begin{array}{c}0.000^{\mathrm{a}} \\
(0.000)\end{array}$ & $\begin{array}{c}7.304^{\mathrm{a}} \\
(1.057)\end{array}$ & $\begin{array}{l}48.855^{\mathrm{b}} \\
(8.771)\end{array}$ & $\begin{array}{l}24.103^{\mathrm{a}} \\
(3.605)\end{array}$ \\
\hline $\begin{array}{l}\text { Commercial } \\
\text { supplier }\end{array}$ & 42 & nd & $\begin{array}{l}28.352^{\mathrm{a}} \\
(3.312)\end{array}$ & $\begin{array}{c}0.017^{\mathrm{a}} \\
(0.017)\end{array}$ & $\begin{array}{l}5.252^{\mathrm{b}} \\
(0.861)\end{array}$ & $\begin{array}{c}82.359^{\mathrm{a}} \\
(16.198)\end{array}$ & $\begin{array}{l}16.372^{\mathrm{b}} \\
(2.703)\end{array}$ \\
\hline
\end{tabular}

*, Number of evaluations of samples; **, standard error of the mean; ***, not detected. Treatments with the same superscript within columns do not differ significantly $(\mathrm{p} \geq 0.05)$. Data representative of French oak extracts of medium toast concentrated by $65 \%(\mathrm{v} / \mathrm{v})$.

\section{TABLE 7}

Gas chromatographic analysis of unmatured pot-still brandy prepared from oak (cooper only) extracts.

\begin{tabular}{|c|c|c|c|c|c|c|c|c|c|}
\hline \multirow[t]{2}{*}{ Type/ Treatment } & \multirow[t]{2}{*}{$\mathrm{n}^{*}$} & \multicolumn{8}{|c|}{ Mean $(\mathrm{mg} / \mathrm{L})$} \\
\hline & & Furfural & $\begin{array}{l}\text { 5-Methyl- } \\
\text { furfural }\end{array}$ & Guaiacol & $\begin{array}{c}\text { trans-oak } \\
\text { Lactone }\end{array}$ & $\begin{array}{c}\text { cis-oak } \\
\text { Lactone }\end{array}$ & $o$-Cresol & Phenol & $\begin{array}{c}\text { Ethyl } \\
\text { guaiacol }\end{array}$ \\
\hline Open & 18 & $\begin{array}{c}26.325^{\mathrm{a}} \\
(3.125)^{* *}\end{array}$ & $\begin{array}{c}0.928^{\mathrm{a}} \\
(0.328)\end{array}$ & $\begin{array}{c}0.660^{\mathrm{b}} \\
(0.067)\end{array}$ & $\mathrm{nd}^{* * *}$ & $\begin{array}{l}0.081^{\mathrm{a}} \\
(0.049)\end{array}$ & nd & nd & $\begin{array}{r}0.006^{\mathrm{a}} \\
(0.006)\end{array}$ \\
\hline Closed & 18 & $\begin{array}{l}25.737^{\mathrm{a}} \\
(2.744)\end{array}$ & $\begin{array}{c}0.798^{\mathrm{a}} \\
(0.263)\end{array}$ & $\begin{array}{l}1.497^{\mathrm{a}} \\
(0.130)\end{array}$ & nd & $\begin{array}{l}0.027^{\mathrm{b}} \\
(0.027)\end{array}$ & nd & nd & $\begin{array}{c}0.000^{\mathrm{a}} \\
(0.000)\end{array}$ \\
\hline Ethanol & 18 & $\begin{array}{l}30.542^{\mathrm{a}} \\
(2.648)\end{array}$ & $\begin{array}{l}1.695^{\mathrm{a}} \\
(0.308)\end{array}$ & $\begin{array}{l}1.096^{\mathrm{a}} \\
(0.152)\end{array}$ & nd & $\begin{array}{l}0.107^{\mathrm{a}} \\
(0.053)\end{array}$ & nd & nd & $\begin{array}{l}0.006^{\mathrm{a}} \\
(0.006)\end{array}$ \\
\hline Water & 18 & $\begin{array}{l}21.520^{\mathrm{a}} \\
(2.810)\end{array}$ & $\begin{array}{c}0.031^{\mathrm{b}} \\
(0.031)\end{array}$ & $\begin{array}{c}1.060^{\mathrm{a}} \\
(0.138)\end{array}$ & nd & $\begin{array}{l}0.000^{\mathrm{b}} \\
(0.000)\end{array}$ & nd & nd & $\begin{array}{c}0.000^{\mathrm{a}} \\
(0.000)\end{array}$ \\
\hline \multirow[t]{2}{*}{ Type/ Treatment } & $\mathbf{n}$ & \multicolumn{8}{|c|}{ Mean $(\mathrm{mg} / \mathrm{L})$} \\
\hline & & \multicolumn{2}{|l|}{$p$-Cresol } & Eugenol & \multicolumn{2}{|c|}{$\begin{array}{l}\text { 2,6-Dimethoxy- } \\
\text { phenol }\end{array}$} & $\begin{array}{l}\text { 5-Hydroxymethyl } \\
\text { furfural }\end{array}$ & \multicolumn{2}{|r|}{ Vanillin } \\
\hline Open & 18 & nd & & $\begin{array}{l}0.021^{\mathrm{a}} \\
(0.021)\end{array}$ & \multicolumn{2}{|c|}{$\begin{array}{l}34.471^{\mathrm{a}} \\
(0.908)\end{array}$} & $\begin{array}{l}6.510^{\mathrm{a}} \\
(1.623)\end{array}$ & \multicolumn{2}{|r|}{$\begin{array}{l}4.469^{\mathrm{a}} \\
(1.554)\end{array}$} \\
\hline Closed & 18 & nd & & $\begin{array}{c}0.000^{\mathrm{a}} \\
(0.000)\end{array}$ & \multicolumn{2}{|c|}{$\begin{array}{l}29.328^{\mathrm{b}} \\
(1.138)\end{array}$} & $\begin{array}{c}6.292^{\mathrm{a}} \\
(1.928)\end{array}$ & \multicolumn{2}{|r|}{$\begin{array}{l}10.073^{\mathrm{a}} \\
(4.033)\end{array}$} \\
\hline Ethanol & 18 & nd & & $\begin{array}{l}0.021^{\mathrm{a}} \\
(0.021)\end{array}$ & \multicolumn{2}{|c|}{$\begin{array}{l}32.409^{\mathrm{a}} \\
(1.134)\end{array}$} & $\begin{array}{l}7.299^{\mathrm{a}} \\
(2.013)\end{array}$ & \multicolumn{2}{|r|}{$\begin{array}{l}10.777^{\mathrm{a}} \\
(3.967)\end{array}$} \\
\hline Water & 18 & nd & & $\begin{array}{c}0.000^{\mathrm{a}} \\
(0.000)\end{array}$ & \multicolumn{2}{|c|}{$\begin{array}{l}31.389^{\mathrm{a}} \\
(1.257)\end{array}$} & $\begin{array}{c}5.503^{\mathrm{a}} \\
(1.484)\end{array}$ & & $\begin{array}{r}3.765^{\mathrm{a}} \\
(1.554)\end{array}$ \\
\hline
\end{tabular}

*, Number of evaluations of samples; $* *$, standard error of the mean; ***, not detected. Treatments with the same superscript within columns do not differ significantly in either water or ethanol medium. Data representative of extracts concentrated by $65 \%(\mathrm{v} / \mathrm{v})$. 
TABLE 8

High-performance liquid chromatographic analysis of unmatured pot-still brandy prepared from oak (cooper only) extracts.

\begin{tabular}{|c|c|c|c|c|c|c|}
\hline \multirow[t]{2}{*}{ Type/Treatment } & \multirow[t]{2}{*}{ n* } & \multicolumn{5}{|c|}{ Mean (mg/L) } \\
\hline & & Gallic acid & Catechin & Vanillic acid & Syringic acid & $p$-Coumaric acid \\
\hline Open & 18 & $\begin{array}{c}6.087^{\mathrm{a}} \\
(0.931)^{* *}\end{array}$ & $\begin{array}{c}3.607^{\mathrm{a}} \\
(1.245)\end{array}$ & $\begin{array}{c}1.358^{a} \\
(0.272)\end{array}$ & $\begin{array}{c}3.401^{\mathrm{a}} \\
(0.594)\end{array}$ & $\begin{array}{c}0.355^{\mathrm{a}} \\
(0.138)\end{array}$ \\
\hline Closed & 18 & $\begin{array}{c}5.407^{\mathrm{a}} \\
(0.795)\end{array}$ & $\begin{array}{c}2.203^{\mathrm{a}} \\
(1.023)\end{array}$ & $\begin{array}{c}1.259^{\mathrm{a}} \\
(0.276)\end{array}$ & $\begin{array}{c}3.310^{\mathrm{a}} \\
(0.535)\end{array}$ & $\begin{array}{c}0.304^{\mathrm{a}} \\
(0.115)\end{array}$ \\
\hline Ethanol & 18 & $\begin{array}{c}6.184^{\mathrm{a}} \\
(0.935)\end{array}$ & $\begin{array}{c}3.736^{\mathrm{a}} \\
(1.255)\end{array}$ & $\begin{array}{c}1.769^{a} \\
(0.306)\end{array}$ & $\begin{array}{c}4.291^{\mathrm{a}} \\
(0.633)\end{array}$ & $\begin{array}{c}0.516^{\mathrm{a}} \\
(0.154)\end{array}$ \\
\hline Water & 18 & $\begin{array}{c}5.310^{\mathrm{a}} \\
(0.783)\end{array}$ & $\begin{array}{c}2.074^{\mathrm{a}} \\
(0.999)\end{array}$ & $\begin{array}{c}0.848^{b} \\
(0.179)\end{array}$ & $\begin{array}{c}2.419^{b} \\
(0.369)\end{array}$ & $\begin{array}{c}0.143^{\mathrm{a}} \\
(0.065)\end{array}$ \\
\hline
\end{tabular}

\begin{tabular}{|c|c|c|c|c|c|c|}
\hline \multirow[t]{2}{*}{ Type/Treatment } & \multirow[t]{2}{*}{$\mathbf{n}$} & \multicolumn{5}{|c|}{ Mean (mg/L) } \\
\hline & & Syringaldehyde & $m$-Coumaric acid & Ellagic acid & Coniferaldehyde & Sinapaldehyde \\
\hline Open & 18 & $\begin{array}{c}5.661^{\mathrm{a}} \\
(1.095)\end{array}$ & $\begin{array}{c}0.266^{\mathrm{a}} \\
(0.063)\end{array}$ & $\begin{array}{l}35.358^{\mathrm{a}} \\
(7.580)\end{array}$ & $\begin{array}{c}8.514^{\mathrm{a}} \\
(1.773)\end{array}$ & $\begin{array}{l}30.894^{\mathrm{a}} \\
(6.023)\end{array}$ \\
\hline Closed & 18 & $\begin{array}{c}6.076^{\mathrm{a}} \\
(1.112)\end{array}$ & $\begin{array}{c}0.207^{\mathrm{a}} \\
(0.069)\end{array}$ & $\begin{array}{l}33.983^{\mathrm{a}} \\
(7.441)\end{array}$ & $\begin{array}{c}7.509^{\mathrm{a}} \\
(1.406)\end{array}$ & $\begin{array}{l}27.659^{\mathrm{a}} \\
(4.777)\end{array}$ \\
\hline Ethanol & 18 & $\begin{array}{c}7.840^{\mathrm{a}} \\
(1.209)\end{array}$ & $\begin{array}{c}0.282^{\mathrm{a}} \\
(0.076)\end{array}$ & $\begin{array}{l}54.574^{\mathrm{a}} \\
(7.975)\end{array}$ & $\begin{array}{l}12.267^{\mathrm{a}} \\
(1.604)\end{array}$ & $\begin{array}{l}42.409^{\mathrm{a}} \\
(6.005)\end{array}$ \\
\hline Water & 18 & $\begin{array}{c}3.897^{\mathrm{b}} \\
(0.723)\end{array}$ & $\begin{array}{c}0.191^{\mathrm{a}} \\
(0.054)\end{array}$ & $\begin{array}{l}14.767^{\mathrm{b}} \\
(1.638)\end{array}$ & $\begin{array}{c}3.757^{\mathrm{b}} \\
(0.669)\end{array}$ & $\begin{array}{l}16.145^{\mathrm{b}} \\
(1.749)\end{array}$ \\
\hline
\end{tabular}

*, Number of evaluations of samples; ${ }^{* *}$, standard error of the mean. Treatments with the same superscript within columns do not differ significantly ( $\mathrm{p} \geq 0.05$ ). Data representative of extracts concentrated by $65 \%(\mathrm{v} / \mathrm{v})$. Open concentration of extracts performed in a $5 \mathrm{~L}$ flask on a heating mantle. Closed concentration performed under vacuum on a rotavap. Extractions performed in either water or ethanol medium.

loss is greater from the more humid storehouses and the quality of brandy better. This may imply that ethanol evaporates from an interface that lies closer to the outer barrel surface under humid, than under low-humidity storage conditions. These findings have important practical implications, since a change in humidity in warehouses will influence the spirit strength and, in turn, the rate of release or hydrolysis of compounds from the wood into the brandy (Guymon \& Crowell, 1970; Reid \& Swan, 1993). Improved extraction of the low molecular weight phenolic substances, including vanillin and gallic acid, in this study (Tables 7 to 10) is in agreement with Singleton (1995). Singleton found that brandies resulting from the higher humidity storage of comparable barrels invariably had at least $15 \%$ higher content of nine low molecular weight phenolic substances, including vanillin and gallic acid, than where storage took place under lower humidity conditions. This author also found water to extract virtually none of these substances. Sixty percent alcohol was more effective as an extractant than $20 \%$ alcohol, but slightly less than $40 \%$, with a possible optimum in the region of $55 \%(\mathrm{v} / \mathrm{v})$. In the present study 55\% (v/v) alcohol, and a much more exhaustive extraction process was followed. This involved distillation and concentration, resulting in determinable concentrations of components, including the aromatic acids (vanillic and syringic acid), and the aromatic or cinnamic and benzoic aldehydes such as syringaldehyde, sinapaldehyde, vanillin and coniferaldehyde (Tables 2 to 10). One concludes that reasonably high concentrations of ethanol in water have different solvent properties than water alone, leading to more effective hydro-alcoholysis of oak. Contrary to findings in this study, some authors reported alcohol extracts of oak chips to be less potent than water extracts with regard to the amount and nature of materials extracted, or in simulating ageing of wines, brandies and other spirits (Singleton \& Draper, 1961).

A two-dimensional plot of F1 and F2 afforded the separation as shown in Figs 4 and 5. Discriminant analysis separated the ethanol- and water-extracted groups of samples into two clusters, overlapping based on the $95 \%$ confidence limits. Clusters related to extraction medium were separated by the second factor, with heterogeneity in the boundary area between two separate clusters. Unmatured pot-still brandies showed more distinct grouping by extraction medium than eight-month matured samples using the first two discriminant functions, which together accounted for $96 \%$ and $78 \%$ of the total variation, respectively (Figs 4 and 5). 
TABLE 9

Gas chromatographic analysis of eight month matured pot-still brandy prepared using oak extracts from different species of oak chips specially prepared by a cooper.

\begin{tabular}{|c|c|c|c|c|c|c|c|c|c|}
\hline \multirow[t]{2}{*}{ Type/ Treatment } & \multirow[t]{2}{*}{$\mathbf{n}^{*}$} & \multicolumn{8}{|c|}{ Mean (mg/L) } \\
\hline & & Furfural & $\begin{array}{l}\text { 5-Methyl- } \\
\text { furfural }\end{array}$ & Guaiacol & $\begin{array}{c}\text { trans-oak } \\
\text { Lactone }\end{array}$ & $\begin{array}{c}\text { cis-oak } \\
\text { Lactone }\end{array}$ & Phenol & $o$-Cresol & $\begin{array}{c}\text { Ethyl } \\
\text { guaiacol }\end{array}$ \\
\hline Open & 48 & $\begin{array}{c}20.658^{\mathrm{a}} \\
(1.656)^{* *}\end{array}$ & $\begin{array}{c}1.094^{\mathrm{a}} \\
(0.227)\end{array}$ & $\begin{array}{c}0.475^{\mathrm{b}} \\
(0.044)\end{array}$ & $\begin{array}{c}0.029^{\mathrm{a}} \\
(0.022)\end{array}$ & $\begin{array}{c}0.137^{\mathrm{a}} \\
(0.044)\end{array}$ & $\begin{array}{c}0.000^{\mathrm{a}} \\
(0.000)\end{array}$ & $\begin{array}{c}0.000^{\mathrm{a}} \\
(0.000)\end{array}$ & $\begin{array}{c}2.315^{\mathrm{b}} \\
(0.062)\end{array}$ \\
\hline Closed & 48 & $\begin{array}{l}20.015^{\mathrm{a}} \\
(1.184)\end{array}$ & $\begin{array}{c}0.842^{\mathrm{a}} \\
(0.172)\end{array}$ & $\begin{array}{c}0.595^{\mathrm{a}} \\
(0.044)\end{array}$ & $\begin{array}{c}0.020^{\mathrm{a}} \\
(0.020)\end{array}$ & $\begin{array}{c}0.070^{\mathrm{a}} \\
(0.032)\end{array}$ & $\begin{array}{c}0.012^{\mathrm{a}} \\
(0.012)\end{array}$ & $\begin{array}{c}0.005^{\mathrm{a}} \\
(0.005)\end{array}$ & $\begin{array}{c}2.598^{a} \\
(0.051)\end{array}$ \\
\hline Ethanol & 48 & $\begin{array}{l}25.578^{a} \\
(1.682)\end{array}$ & $\begin{array}{c}1.799^{\mathrm{a}} \\
(0.219)\end{array}$ & $\begin{array}{c}0.536^{\mathrm{a}} \\
(0.044)\end{array}$ & $\begin{array}{c}0.049^{\mathrm{a}} \\
(0.030)\end{array}$ & $\begin{array}{c}0.185^{\mathrm{a}} \\
(0.050)\end{array}$ & $\begin{array}{c}0.012^{\mathrm{a}} \\
(0.012)\end{array}$ & $\begin{array}{c}0.005^{\mathrm{a}} \\
(0.005)\end{array}$ & $\begin{array}{c}2.393^{b} \\
(0.076)\end{array}$ \\
\hline Water & 48 & $\begin{array}{l}15.096^{\mathrm{b}} \\
(0.390)\end{array}$ & $\begin{array}{c}0.136^{\mathrm{b}} \\
(0.067)\end{array}$ & $\begin{array}{r}0.534^{\mathrm{a}} \\
(0.045)\end{array}$ & $\begin{array}{c}0.000^{\mathrm{b}} \\
(0.000)\end{array}$ & $\begin{array}{c}0.022^{b} \\
(0.016)\end{array}$ & $\begin{array}{c}0.000^{\mathrm{a}} \\
(0.000)\end{array}$ & $\begin{array}{c}0.000^{\mathrm{a}} \\
(0.000)\end{array}$ & $\begin{array}{l}2.520^{\mathrm{a}} \\
(0.037)\end{array}$ \\
\hline
\end{tabular}

\begin{tabular}{|c|c|c|c|c|c|c|}
\hline \multirow[t]{2}{*}{ Type/ Treatment } & \multirow[t]{2}{*}{$\mathbf{N}$} & \multicolumn{5}{|c|}{ Mean (mg/L) } \\
\hline & & $p$-Cresol & Eugenol & 2,6-Dimethoxy-phenol & $\begin{array}{c}\text { 5-Hydroxymethyl } \\
\text { furfural }\end{array}$ & Vanillin \\
\hline Open & 48 & $\begin{array}{c}0.000^{\mathrm{a}} \\
(0.000)\end{array}$ & $\begin{array}{c}0.153^{\mathrm{b}} \\
(0.030)\end{array}$ & $\begin{array}{l}34.405^{b} \\
(0.426)\end{array}$ & $\begin{array}{l}3.806^{\mathrm{a}} \\
(0.380)\end{array}$ & $\begin{array}{l}2.750^{\mathrm{b}} \\
(0.307)\end{array}$ \\
\hline Closed & 48 & $\begin{array}{r}0.011^{\mathrm{a}} \\
(0.011)\end{array}$ & $\begin{array}{l}0.239^{\mathrm{a}} \\
(0.043)\end{array}$ & $\begin{array}{l}36.910^{\mathrm{a}} \\
(0.458)\end{array}$ & $\begin{array}{l}4.032^{\mathrm{a}} \\
(0.402)\end{array}$ & $\begin{array}{l}3.995^{\mathrm{a}} \\
(0.429)\end{array}$ \\
\hline Ethanol & 48 & $\begin{array}{c}0.011^{\mathrm{a}} \\
(0.011)\end{array}$ & $\begin{array}{l}0.230^{\mathrm{a}} \\
(0.046)\end{array}$ & $\begin{array}{l}35.548^{\mathrm{a}} \\
(0.483)\end{array}$ & $\begin{array}{c}4.076^{\mathrm{a}} \\
(0.408)\end{array}$ & $\begin{array}{l}4.186^{\mathrm{a}} \\
(0.443)\end{array}$ \\
\hline Water & 48 & $\begin{array}{c}0.000^{\mathrm{a}} \\
(0.000)\end{array}$ & $\begin{array}{c}0.163^{\mathrm{a}} \\
(0.025)\end{array}$ & $\begin{array}{l}35.768^{\mathrm{a}} \\
(0.475)\end{array}$ & $\begin{array}{c}3.762^{\mathrm{a}} \\
(0.373)\end{array}$ & $\begin{array}{c}2.559^{\mathrm{b}} \\
(0.264)\end{array}$ \\
\hline
\end{tabular}

*, Number of evaluations of samples; $* *$, standard error of the mean. Treatments with the same superscript within columns do not differ significantly ( $\mathrm{p} \geq 0.05$ ). Data representative of extracts concentrated by $65 \%(\mathrm{v} / \mathrm{v})$. Open concentration of extracts performed in a $5 \mathrm{~L}$ flask on a heating mantle. Closed concentration performed under vacuum on a rotavap. Extractions performed in either water or ethanol medium.

\section{Open versus reduced-pressure concentration}

\section{Extracts}

Sensory evaluation indicated that those extracts that were concentrated open, under atmospheric pressure, on a heating mantle were more acceptable than those prepared under reduced pressure (Fig. 1).

\section{Unmatured pot-still brandy}

Generally, for detectable oak-derived congeners, the use of open concentration in the preparation of extracts yielded significantly higher and lower concentrations of the volatile compounds cis-oak lactone and 2,6-dimethoxyphenol, and guaiacol, respectively, in unmatured pot-still brandy than where concentration was carried out under reduced pressure (Table 7). The concentrations of less volatile wood-derived congeners in unmatured pot-still brandy prepared from extracts that were concentrated open, generally (except for syringaldehyde) were equally to slightly higher $(\mathrm{p} \geq 0.05)$ to those concentrated under reduced pressure (Table 8).

\section{Eight-month matured pot-still brandy}

Eight-month matured pot-still brandy prepared with extracts that were concentrated under reduced pressure were generally equally or slightly more acceptable sensorally $(\mathrm{p} \geq 0.05)$ than those concentrated open (Fig. 3).

The concentration of the volatile wood-derived congeners guaiacol, ethyl guaiacol, eugenol, 2,6-dimethoxyphenol and vanillin in eight-month matured pot-still brandy prepared with extracts concentrated under reduced pressure were higher $(\mathrm{p} \leq 0.05)$ than those concentrated open (Table 9).

The concentrations of the less volatile wood-derived congeners catechin and gallic-, syringic- and ellagic acids in eight-month matured pot-still brandy prepared with extracts concentrated under reduced pressure were mostly lower or higher (protocatechuic acid) $(p \leq 0.05)$ than where concentration was performed under open conditions. However, this was only the case where the chips from which the brandies were ultimately made came from the cooper (Table 10). The opposite was observed where the chips were obtained from a commercial supplier (results not shown).

Discriminant analysis separated the open- and closed classes or groups into two clusters, overlapping based on the $95 \%$ confidence limits. Clusters related to extraction medium were separated by the first factor (Fig. 4). Unmatured pot-still brandies showed more 


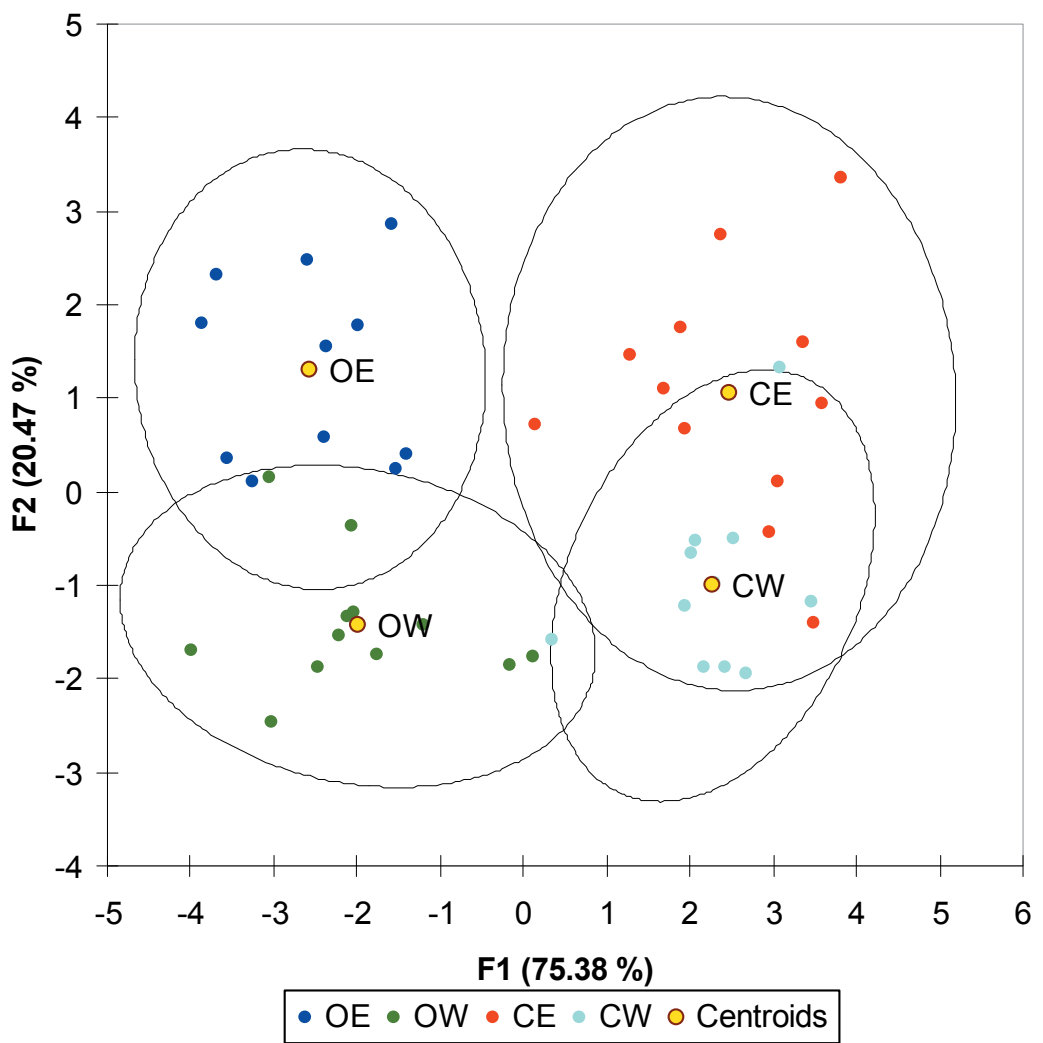

FIGURE 4

Plot of discriminant scores of the first two discriminant factors (F1, F2) of unmatured extract/pot-still brandies for the treatment classes open (O)/closed (C) x ethanol (E)/ water (W), defined by the variables percent acceptability, furfural, 5-methylfurfural, guaiacol, cis-oak lactone, 2,6-dimethoxyphenol, 5-hydroxymethyl furfural, vanillin, gallic acid, catechin, vanillic acid, syringic acid, $p$-coumaric acid, syringaldehyde, $m$-coumaric acid, ellagic acid, coniferaldehyde and sinapaldehyde.

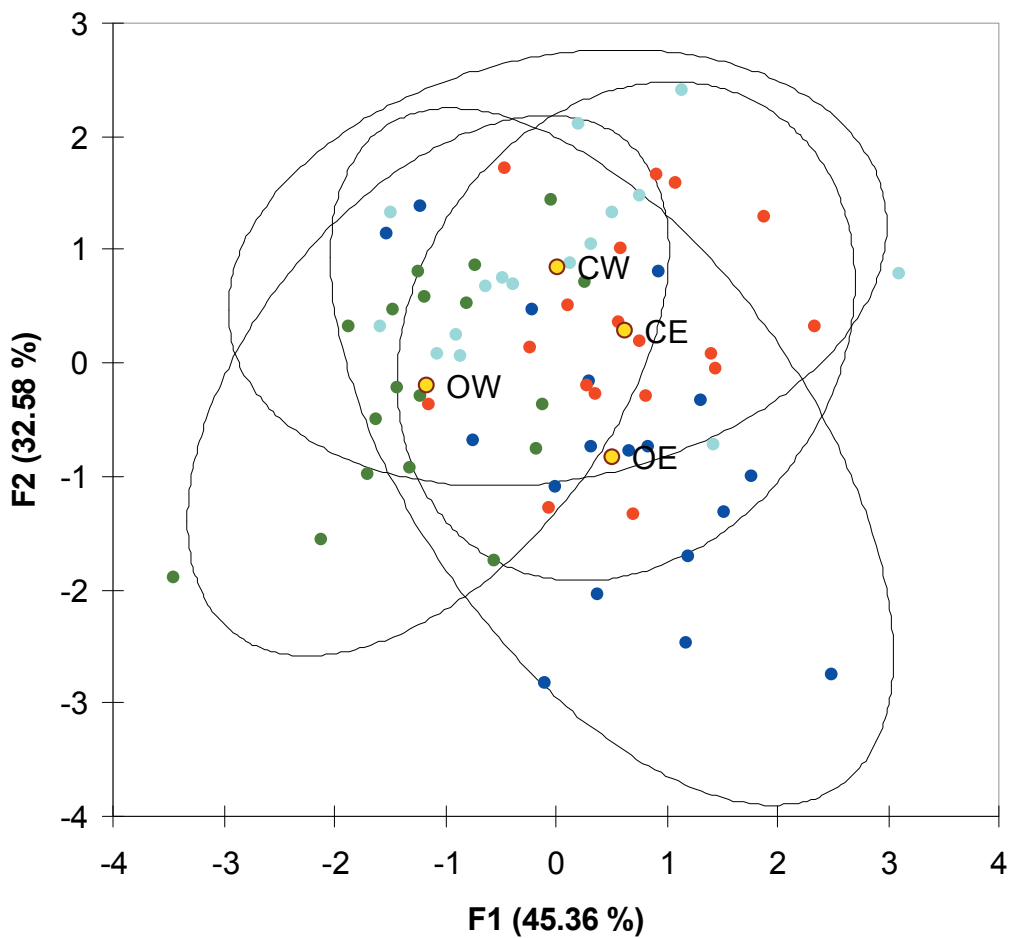

$\cdot \mathrm{OE} \cdot \mathrm{OW} \cdot \mathrm{CE} \cdot \mathrm{CW} \circ$ Centroids

FIGURE 5

Plot of discriminant scores of the first two discriminant factors (F1, F2) of eight-month matured pot-still brandies for the treatment classes open (O)/closed (C) x ethanol $(\mathrm{E}) /$ water $(\mathrm{W})$, defined by the variables herbaceous, fruity, woody, sweet associated, toasted, other positive, other negative and overall quality. 
TABLE 10

High-performance liquid chromatographic analysis of eight-month matured pot-still brandy prepared from oak (cooper only) extracts.

\begin{tabular}{|c|c|c|c|c|c|c|c|c|}
\hline \multirow[t]{2}{*}{ Type/Treatment } & \multirow[t]{2}{*}{$\mathbf{n}^{*}$} & \multicolumn{7}{|c|}{ Mean (mg/L) } \\
\hline & & Gallic acid & $\begin{array}{l}\text { Proto- } \\
\text { catachuic acid }\end{array}$ & $\begin{array}{l}p \text {-Hydroxy- } \\
\text { benzoic acid }\end{array}$ & Catechin & Vanillic acid & Syringic acid & $\begin{array}{l}p \text {-Coumaric } \\
\text { acid }\end{array}$ \\
\hline Open & 48 & $\begin{array}{c}4.616^{\mathrm{a}} \\
(0.575)^{* *}\end{array}$ & $\begin{array}{c}0.169^{\mathrm{b}} \\
(0.089)\end{array}$ & $\begin{array}{c}0.444^{\mathrm{a}} \\
(0.137)\end{array}$ & $\begin{array}{c}1.976^{\mathrm{a}} \\
(0.908)\end{array}$ & $\begin{array}{c}1.520^{\mathrm{a}} \\
(0.203)\end{array}$ & $\begin{array}{c}2.885^{\mathrm{a}} \\
(0.352)\end{array}$ & $\begin{array}{c}0.014^{\mathrm{a}} \\
(0.010)\end{array}$ \\
\hline Closed & 48 & $\begin{array}{c}3.626^{\mathrm{b}} \\
(0.467)\end{array}$ & $\begin{array}{c}0.815^{\mathrm{a}} \\
(0.171)\end{array}$ & $\begin{array}{c}0.347^{\mathrm{a}} \\
(0.110)\end{array}$ & $\begin{array}{c}0.428^{\mathrm{b}} \\
(0.184)\end{array}$ & $\begin{array}{c}1.321^{\mathrm{a}} \\
(0.174)\end{array}$ & $\begin{array}{c}2.594^{\mathrm{b}} \\
(0.319)\end{array}$ & $\begin{array}{c}0.000^{\mathrm{a}} \\
(0.000)\end{array}$ \\
\hline Ethanol & 48 & $\begin{array}{c}4.472^{\mathrm{a}} \\
(0.587)\end{array}$ & $\begin{array}{c}0.482^{\mathrm{a}} \\
(0.140)\end{array}$ & $\begin{array}{c}0.570^{\mathrm{a}} \\
(0.144)\end{array}$ & $\begin{array}{c}1.642^{\mathrm{a}} \\
(0.902)\end{array}$ & $\begin{array}{c}1.516^{\mathrm{a}} \\
(0.199)\end{array}$ & $\begin{array}{c}3.464^{\mathrm{a}} \\
(0.396)\end{array}$ & $\begin{array}{c}0.006^{\mathrm{a}} \\
(0.006)\end{array}$ \\
\hline Water & 48 & $\begin{array}{c}3.770^{\mathrm{b}} \\
(0.458)\end{array}$ & $\begin{array}{c}0.501^{\mathrm{a}} \\
(0.149)\end{array}$ & $\begin{array}{c}0.221^{\mathrm{b}} \\
(0.095)\end{array}$ & $\begin{array}{c}0.762^{b} \\
(0.246)\end{array}$ & $\begin{array}{c}1.325^{\mathrm{a}} \\
(0.179)\end{array}$ & $\begin{array}{c}2.015^{\mathrm{b}} \\
(0.217)\end{array}$ & $\begin{array}{c}0.008^{\mathrm{a}} \\
(0.008)\end{array}$ \\
\hline
\end{tabular}

\begin{tabular}{|c|c|c|c|c|c|c|}
\hline \multirow[t]{2}{*}{ Type/Treatment } & \multirow[t]{2}{*}{$\mathbf{n}$} & \multicolumn{5}{|c|}{ Mean (mg/L) } \\
\hline & & Syringaldehyde & $m$-Coumaric acid & Ellagic acid & Coniferaldehyde & Sinapaldehyde \\
\hline Open & 48 & $\begin{array}{c}9.260^{\mathrm{a}} \\
(1.035)\end{array}$ & $\begin{array}{c}0.030^{\mathrm{a}} \\
(0.013)\end{array}$ & $\begin{array}{c}5.287^{\mathrm{a}} \\
(0.666)\end{array}$ & $\begin{array}{l}29.760^{\mathrm{a}} \\
(4.155)\end{array}$ & $\begin{array}{l}15.848^{\mathrm{a}} \\
(2.243)\end{array}$ \\
\hline Closed & 48 & $\begin{array}{c}9.103^{\mathrm{a}} \\
(0.998)\end{array}$ & $\begin{array}{c}0.014^{\mathrm{a}} \\
(0.008)\end{array}$ & $\begin{array}{c}4.315^{b} \\
(0.551)\end{array}$ & $\begin{array}{l}26.588^{a} \\
(3.955)\end{array}$ & $\begin{array}{l}14.812^{\mathrm{a}} \\
(2.013)\end{array}$ \\
\hline Ethanol & 48 & $\begin{array}{l}11.907^{\mathrm{a}} \\
(1.210)\end{array}$ & $\begin{array}{c}0.017^{\mathrm{a}} \\
(0.010)\end{array}$ & $\begin{array}{c}6.903^{\mathrm{a}} \\
(0.698)\end{array}$ & $\begin{array}{l}44.220^{\mathrm{a}} \\
(4.595)\end{array}$ & $\begin{array}{l}22.865^{\mathrm{a}} \\
(2.439)\end{array}$ \\
\hline Water & 48 & $\begin{array}{c}6.456^{\mathrm{b}} \\
(0.535)\end{array}$ & $\begin{array}{c}0.026^{\mathrm{a}} \\
(0.012)\end{array}$ & $\begin{array}{c}2.699^{b} \\
(0.287)\end{array}$ & $\begin{array}{l}12.129^{b} \\
(0.969)\end{array}$ & $\begin{array}{c}7.795^{\mathrm{b}} \\
(0.855)\end{array}$ \\
\hline
\end{tabular}

*, Number of evaluations of samples; **, standard error of the mean. Treatments with the same superscript within columns do not differ significantly ( $\mathrm{p} \geq 0.05$ ). Data representative of extracts concentrated by $65 \%(\mathrm{v} / \mathrm{v})$. Open concentration of extracts performed in a $5 \mathrm{~L}$ flask on a heating mantle. Closed concentration performed under vacuum on a rotavap. Extractions performed in either water or ethanol medium.

distinct grouping by extraction method than eight-month matured samples using the first two discriminant functions, which together accounted for $96 \%$ and $78 \%$ of the total variation, respectively (Figs 4 and 5).

\section{CONCLUSIONS}

The treatments that yielded the highest quality products from a sensorial viewpoint were those that included a concentration of $65 \%(\mathrm{v} / \mathrm{v})$, and ethanol, rather than water as extraction medium. Pot-still brandy prepared with oak chips specially prepared by a cooper fared better than commercial chips, thus proving the importance of knowing the specifics regarding the seasoning and preparation of oak staves and having a good understanding with suppliers. Although open concentration initially yielded products of higher quality than reduced-pressure concentration, the beneficial effects were no longer prominent after eight months maturation. It follows that there is a definite relationship between treatment, wood-derived congener concentrations and pot-still brandy quality. Although recommendations regarding single treatments can be made, it must be borne in mind that it is not always a single treatment, but a combination of various practices, that yield the best quality products.
Development of techniques to rapidly induce ageing character in brandy products should use ethanol instead of water as extraction medium, and higher levels (at least $65 \%, \mathrm{v} / \mathrm{v}$ ) of concentration.

\section{LITERATURE CITED}

Baldwin, S., Black, R.A., Andreasen, A.A. \& Adams, S.L. 1967. Aromatic congener formation in maturation of alcoholic distillates. J. Agr. Food Chem. 15, 381385 .

Canas, S., Leandro, M.C., Spranger, M.I. \& Belchior, A.P., 1999. Low molecular weight organic compounds of chestnut wood (Castanea sativa L.) and corresponding aged brandies. J. Agric. Food Chem. 47, 5023-5030.

Case, M. \& van Wyk, C.J., 1989. Die effek van die oorsprong en die roosterintensiteit op die aroma samestelling en aanvaarbaarheid van eikehout vir wynveroudering. Wynboer, November, 6.

Cerdán, T.G., Goñi, D.T. \& Azpilicueta, C.A., 2002. Changes in the concentration of volatile oak compounds and esters in red wine stored for 18 months in re-used French oak barrels. Aust. J. Grape Wine Res. 8, 140-145.

Chatonnet, P., 1999. Volatile and odoriferous compounds in barrel-aged wines: impact of cooperage techniques and aging conditions. In: Waterhouse, A.L. \& Ebeler, S.E. (eds). Chemistry of Wine Flavor. 1999 - ACS Symposium Series no. 714. American Chemical Society, Washington D.C. pp. 180-207.

Conner, J.M., Paterson, A. \& Piggott, J.R., 1994. Agglomeration of ethyl esters in model spirit solutions and malt whiskies. J. Sci. Food Agric. 66, 45-53. 
Conner, J.M., Paterson, A., Birkmyre, L. \& Piggott, J.R., 1999. Role of organic acids in maturation of distilled spirits in oak casks. J. Inst. Brew. 105, 287-291

Firstenfeld, J., 2002. Oak chips in season. Wines \& Vines 83, 68-72.

Francis, I.J., Sefton, M.A. \& Williams, P.J., 1992. A Study by sensory descriptive analysis of the effects of oak origin, seasoning, and heating on the aromas of oak model wine extracts. Am. J. Enol. Vitic. 43, 23-30.

Giménez Martínez, R., López García De La Serrana, H., Villalón Mir, M., Navarro Alarcón, M., Olalla Herrera, M., Cabrera Vique, C. \& López Martínez, M.C., 2001. Study of vanillin syringaldehyde and gallic acid content in oak wood and wine spirits mixtures: Influence of heat treatment and chip size. J. Wine Res. 12, 175-182.

Godden, P.W., Pollnitz, A.P., Osicka, S., Sykes, M., Liacopoulos, D., Pardon, K.H., Spillman, P.J., Gawel, R., Jones, G.P., Skluoumounis, G.K. \& Sefton, M.A., 1999. Measuring desirable oakwood components in wine. In: Blair, R.J., Sas, A.N., Hayes, P.F. \& Høj, P.B. (eds). Proc. $10^{\text {th }}$ Australian Wine Ind. Tech. Conf., 2-5 August 1998, Sydney, New South Wales, Australia. pp. 121-124.

Guymon, J.F. \& Crowell, E.A., 1970. Some comparisons of American and French oak cooperage. Wines \& Vines 51, 23-25.

Hacker, W.F., 1991a. Die houtvat - sy eienskappe en invloed op wyn. Wynboer, May, 12.

Hacker, W.F., 1991b. Die houtvat - sy eienskappe en invloed op wyn. Wynboer, July, 3-4.

Hacker, W.F., 1991c. Die houtvat - sy eienskappe en invloed op wyn. Wynboer, October, 6-7.

Hale, M.D., McCafferty, K., Larmie, E., Newton, J. \& Swan, J.S., 1999. The influence of oak seasoning and toasting parameters on the composition and quality of wine. Am. J. Enol. Vitic. 50, 495-502.

Jindra, J.A. \& Gallander, J.F., 1987. Effect of American and French oak barrels on the phenolic composition and sensory quality of Seyval blanc wines. Am. J. Enol. Vitic. 38, 133-138.

László, J., 1995. Wine-maturation in oak barrels in South Africa. Wynboer, September, 40-44.

Litchev, V., 1989. Influence of oxidation processes on the development of the taste and flavor of wine distillates. Am. J. Enol. Vitic. 40, 31-35.

Masson, E., Baumes, R., Le Guernevé, C. \& Puech, J.-L., 2000. Identification of a precursor of $\beta$-methyl- $\gamma$-octalactone in the wood of sessile oak (Quercus petraea (Matt.) Liebl.). J. Agric. Food Chem. 48, 4306-4309.

Masson, G., Guichard, E., Fournier, N. \& Puech, J.-L., 1995. Stereoisomers of $\beta$ methyl- $\gamma$-octalactone. II. Contents in the wood of French (Quercus robur and Quercus petraea) and American (Quercus alba) oaks. Am. J. Enol. Vitic. 46, 424-428.

Matricardi, L. \& Waterhouse, A.L., 1999. Influence of toasting technique on color and ellagitannins of oak wood in barrel making. Am. J. Enol. Vitic. 50, 519-526.

Miller, D.P., Howell, G.S., Michaelis, C.S. \& Dickmann, D.I., 1992. The content of phenolic acid and aldehyde flavor components of white oak as affected by site and species. Am. J. Enol. Vitic. 43, 333-338.

Mosedale, J.R. \& Puech, J-L., 1998. Wood maturation of distilled beverages. Trends in Food Sci. \& Technol. 9, 95-101.

Pérez-Coello, M.S., Sanz, J. \& Cabezudo, M.D., 1999. Determination of volatile compounds in hydroalcoholic extracts of French and American oak wood. Am. J. Enol. Vitic. 50, 162-165.

Pocock, K.F., Sefton, M.A. \& Williams, P.J., 1994. Taste thresholds of phenolic extracts of French and American oakwood: The influence of oak phenols on wine flavor. Am. J. Enol. Vitic. 45, 429-434.

Puech, J-L., 1984. Characteristics of oak wood and Biochemical aspects of Armagnac aging. Am. J. Enol. Vitic. 35, 77-81.
Puech, J-L., 1987. Extraction of phenolic compounds from oak wood in model solutions and evolution of aromatic aldehydes in wines aged in oak barrels. Am. J. Enol. Vitic. 38, 236-238.

Puech, J-L., 1988. Phenolic compounds in oak wood extracts used in the ageing of brandies. J. Sci. Food Agric. 42, 165-172.

Puech, J.-L., Feuillat, F. \& Mosedale, J.R., 1999. The tannins of oak heartwood: Structure, properties, and their influence on wine flavor. Am. J. Enol. Vitic. 4, 469-478.

Reid, K.J.G. \& Swan, J.S., 1993. Assessment of Scotch whiskey quality by pyrolysis-mass spectometry and the subsequent correlation of quality with the oak wood cask. J. Anal. Appl. Pyrol. 25, 49-62.

SAS, 2000. SAS/STAT Users Guide, Version 8, First Edition, Volume 2. SAS Institute Inc., Cary, NC, USA.

Sauvageot, F. \& Feuillat, F., 1999. The influence of oak wood (Quercus robur L., $Q$. petraea Liebl.) on the flavor of Burgundy Pinot noir. An examination of variation among individual trees. Am. J. Enol. Vitic. 50, 447-455.

Sefton, M.A., Spillman, P.J., Pocock, K.F., Francis, L.L. \& Williams, P.J., 1993. The influence of oak origin, seasoning, and other industry practices on the sensory characteristics and composition of oak extracts and barrel-aged white wines. Aust. Grapegrower Winemaker No. 355, July 1993, 17-25.

Sefton, M.A. \& Spillman, P.J., 1995. The influences of oak, coopering heat and microbial activity on oak-derived wine aroma. In: Stockley, C.S., Sas, A.N., Johnstone, R.S. \& Lee, T.H. (eds.). Proc. $9^{\text {th }}$ Aust. Wine Ind. Tech. Conf., 16-19 July 1995, Adelaide, South Australia. pp. 66-71.

Shapiro, S.S. \& Wilk, M.B., 1965. An analysis of Variance Test for Normality (complete samples), Biometrika 52, 591-611.

Singleton, V.L., 1974. Some aspects of the wooden container as a factor in wine maturation. In: Dinsmoor Webb, A. (ed.). Chemistry of Wine Making, Advances in Chemistry Series, 137. American Chemical Society, Washington D.C. pp. 254-277.

Singleton, V.L., 1995. Maturation of wines and spirits: comparisons, facts, and hypothesis. Am. J. Enol. Vitic. 46, 98-115.

Singleton, V.L. \& Draper, D.E., 1961. Wood chips and wine treatment: The nature of aqueous alcohol extracts. Am. J. Enol. Vitic. 12, 152-158.

Smith, F., 2002. Scraping the barrel for recycling. Wines \& Vines. January 2002, $134-135$.

Spillman, P.J., Sefton, M.A. \& Gawel, R., 2004. The effect of oak wood source, location of seasoning and cooperage on the composition of volatile compounds in oak-matured wines. Aust. J. Grape Wine Res. 10, 216-226.

Suomalainen, H. \& Nykänen, L., 1972. Formation of aroma compounds in alcoholic beverages. Wallerst. Lab. Comm. XXXV, 185-198.

Suomalainen, H., Nykänen, L. \& Eriksson, K., 1974. Composition and consumption of alcoholic beverages - a review. Am. J. Enol. Vitic. 25, 179-186.

Venkataramu, K., Patel, J.D. \& Subba Rao, M.S., 1983. Fractionation of wood phenolics and their use in brandy. J. Food Sci. Technol. 20, 16-18.

Venter, W.P., 1985. Die vatveroudering van brandewyn. Wynboer, July, 29-30.

Venter, W.P., 1994. Die sintuiglike beoordeling van potketelbrandewyn. Wynboer, November, 10-12.

Vivas, N., 2000. Recent acquisitions concerning oak wood for cooperage and red wines ageing in barrels. Bulletin de l'O.I.V. 73 (827/828), 79-108.

Vivas, N. \& Saint-Cricq de Gaulejac, N., 1999. The useful lifespan of new barrels and risk related to the use of old barrels. Aust. N.Z. Wine Ind. J. 14, 37-45.

Wagener, N., 1986. The effect of off-flavours of distilling wines on the quality of brandy. Wynboer, July, 5. 